Anuario del Instituto de Historia Argentina, diciembre 2018, vol. 18, n² 2, e075. ISSN 2314-257X

Universidad Nacional de La Plata

Facultad de Humanidades y Ciencias de la Educación

Centro de Historia Argentina y Americana

\title{
Erogaciones fiscales, suministros militares y deudas. La distribución de los fondos del Real Situado en Buenos Aires entre 1766 y 1772
}

\author{
Martín L. E. Wasserman \\ Universidad de Buenos Aires-CONICET, Argentina \\ mwasserman@filo.uba.ar
}

\begin{abstract}
Cita sugerida: Wasserman, M. L. E. (2018). Erogaciones fiscales, suministros militares y deudas. La distribución de los fondos del Real Situado en Buenos Aires entre 1766 y 1772. Anuario del Instituto de Historia Argentina, 18(2), e075. https://doi.org/10.24215/2314257Xe075
\end{abstract}

Recibido: 18 junio 2018 - Aceptado: 24 septiembre 2018 - Publicado: 07 diciembre 2018

(c) (i) (2)(2) Esta obra está bajo licencia Creative Commons Atribución-NoComercial-CompartirIgual 4.0 Internacional
http://creativecommons.org/licenses/by-nc-sa/4.0/deed.es_AR 


\section{Erogaciones fiscales, suministros militares y deudas. La distribución de los fondos del Real Situado en Buenos Aires entre 1766 y 1772}

Fiscal expenditures, military supplies and debts. Distributing the funds of the Real Situado in Buenos Aires between 1766 and 1772

Martin L. E. Wasserman

Universidad de Buenos Aires-CONICET, Argentina

mwasserman@filo.uba.ar

\section{Resumen:}

La gestión de las erogaciones del Real Situado en una Caja receptora, como la de Buenos Aires, permite comprender las prioridades en la adjudicación de los recursos, pero también explica el modo en que eran dispensados y los mecanismos con que se desplegaba el financiamiento de los gastos implicados en la defensa. Considerando que el ramo del Situado representaba el rubro fiscal con mayor peso en la tesorería local, los mecanismos articulados por la Real hacienda borbónica para financiar los gastos implicados en suministros militares constituyen un observatorio clave para identificar cómo era gobernado y administrado el Erario imperial, en la escala local, durante una coyuntura crítica para el gobierno de la monarquía española: las reconfiguraciones en la defensa y en la Hacienda real después de la Guerra de los Siete Años.

Palabras Clave: Distribución de recursos fiscales, Real Situado, Deudas, Buenos Aires, Siglo XVIII.

\section{Abstract:}

The management of the expenditures of the Real Situado in its receiver treasury (like the Buenos Aires one) allows to understand both the priorities in the allocation of the resources, as well as the way in which they were dispensed and the mechanisms deployed to finance the expenses of the defense. Considering that the Real Situado represented the fiscal item with greater weight in the local treasury, the mechanisms articulated by the Royal Treasury to finance the expenses involved in military supplies for defense constitute a key observatory to identify how the imperial Royal Treasury was governed and administered in its local scale during a critic situation for the Spanish crown: the reconfigurations of the defense and the Real Hacienda after the Seven Years' War.

KEYWORDS: Fiscal Resources Distribution, Real Situado, Debts, Buenos Aires, XVIIIth Century.

\section{INTRODUCCIÓN}

El Real Situado constituyó un sistema de transferencias interregionales de recursos fiscales, redistribuidos por cuenta del rey entre distintas tesorerías para cubrir gastos que interesaban a la corona. En Hispanoamérica, durante los siglos XVII y XVIII, este mecanismo fue primordialmente empleado para que distritos con sólidas bases fiscales subsidiasen a tesorerías ubicadas en puntos estratégicos para la defensa del Imperio, allí cuando sus recursos impositivos locales resultaban insuficientes para afrontar los gastos defensivos ${ }^{1}$. Por ello, la remisión de estos fondos al bastión de Buenos Aires constituyó un factor elemental para asegurar la integridad del espacio meridional hispanoamericano ante las presiones de otras potencias, lo que garantizaba a un mismo tiempo la propia pervivencia de Buenos Aires en el mapa imperial y habilitaba, consecuentemente, el crecimiento de la economía porteña durante el siglo XVIII ${ }^{2}$.

Esta movilización de caudales implicó, sin embargo, el despliegue de negocios, pactos y tensiones en los intersticios de la institucionalidad formalmente reconocida: mercaderes, grandes comerciantes, oficiales reales, militares de alto rango, instituciones eclesiásticas y gobernadores encontraban en el Situado una vía posible para captar fondos del Erario con los cuales desplegar prácticas comerciales y financieras, razón por la cual el mecanismo de remisiones hacía confluir a los intereses lucrativos de estos actores con los intereses defensivos de la Corona ${ }^{3}$. Con ello, la intervención de estos actores condicionaba el funcionamiento del 
Situado, a la vez que expresaba la capacidad de las oligarquías locales para participar en los términos con los que se desenvolvía la fiscalidad regia en los territorios americanos ${ }^{4}$. Y esta tácita negociación en la arena fiscal sobreviviría a los Habsburgo, expresada en una maquinaria fiscal de base redistributiva que matizaba las virtudes centralizadoras tradicionalmente atribuidas al reformismo borbónico ${ }^{5}$.

El desembolso o "distribución" de estos recursos en la plaza receptora constituía, por lo tanto, una instancia clave en el proceso de transferencias interregionales del Real Situado. Dadas sus potestades jurisdiccionales, los oficiales reales de la Hacienda "distribuían" aquellos fondos según procedimientos normativamente regulados, asentando su entrega en la datade los libros contables con arreglo a un lenguaje administrativo que legitimaba el descargo de los recursos (Sánchez Santiró, 2013). Constituía así una instancia reconocida por la normativa hacendaria, en la cual se legalizaban oportunamente algunas de aquellas prácticas de capitalización comercial y financiera, adaptándolas a finalidades aceptadas y confiriéndoles un cariz formalmente adecuado a la normativa. Pero constituía, en suma, una instancia en la que los fondos transferidos eran puestos formalmente en contacto con distintos actores de la economía local y de otras economías regionales, destinatarias asimismo de recursos redistribuidos por la Real Caja receptora. A partir de su distribución local y regional, estos influjos monetarios habrían ejercido un efecto dinamizador sobre las economías receptoras ${ }^{6}$.

En este sentido, si la caracterización del dominio español en Hispanoamérica como netamente coercitivo y extractivo de rentas era matizada al evidenciase la participación que distintos actores tenían informalmente sobre los recursos fiscales en los intersticios del Real Situado, la presunta dinamización económica estimulada por aquellos desembolsos, institucionalmente canalizados y formalmente reconocidos, vendría a complementar aquellos matices desde los mecanismos aceptados por el propio sistema.

En el presente artículo se propone, entonces, un avance sobre la administración del desembolso de los fondos del Real Situado de Buenos Aires, para contribuir desde el caso bonaerense al conocimiento sobre la incidencia que dichos flujos tuvieron en el desempeño de la economía, durante los años que corren entre 1766 (año en que inicia la confección de los libros del ramo de Situados) y 1772 (cuando la creación de los regimientos fijos de Infantería y Dragones amplían las filas de receptores del Situado, hecho que dinamiza a partir de entonces las remisiones de caudales).

Ello permitirá ofrecer respuestas tentativas al interrogante sobre la relación entre centralización y negociación en la Hacienda borbónica, a la luz de la medular importancia que detentaba el desembolso de recursos fiscales para el suministro de la defensa militar en la frontera del Imperio, tras la Guerra de los Siete Años ${ }^{7}$.

\section{La creciente gravitación de Buenos Aires en el esquema de la Real Hacienda RIOPLATENSE}

Las estimaciones poblacionales conocidas para Buenos Aires durante este período indican la existencia de unos 17.633 habitantes en 1744, los cuales habrían ascendido a unos 22.007 en 1770, para dar un salto a las 37.000 personas en 1778, cuando se acelera el crecimiento demográfico de Buenos Aires, ya por entonces cabecera del flamante Virreinato del Río de la Plata desde el año previo (Cuesta, 2009, p. 37; Concolorcorvo, 2005 [1773], pp. 11-12; Gelman, 2012, p. 102). Sobre esta población creciente sobresalía la presencia de unas fuerzas militares de composición cambiante: los más de 3.000 efectivos de unidades veteranas reportados entre las décadas de 1760 y comienzos de la de 1770 encontraban complemento en un número expansivo de efectivos reclutados para las milicias, que pasarían de los 6.750 en 1765 a los 7.470 en 1774 (Beverina, 1992 [1935], pp. 199 y ss.; Fradkin, 2012, pp. 249 y ss.). Si algunas de estas estimaciones permiten sugerir que en la década de 1760 había un soldado veterano cada doce habitantes de la ciudad de Buenos Aires, el protagonismo de la población militar asciende considerablemente cuando se contempla a las filas de las milicias ${ }^{8}$. 
En un contexto de intensa conflictividad en el Río de la Plata, eran los sueldos de estas dotaciones los que justificaban una transferencia de fondos de envergadura cada vez mayor desde otras tesorerías, primordialmente las de Potosí, hacia Buenos Aires y por el conducto del Real Situado.

\section{II.1. Real Situado y coyunturas}

Tal como se hubiese explicado en otra ocasión (Autor/a, 2017), entre 1760 y 1790 los cimientos institucionales y fiscales se modifican en Buenos Aires al compás de la conflictividad imperial y de su crecimiento económico (Gelman y Moraes, 2014) ${ }^{9}$. Durante dicho período, el Real Situado incrementa radicalmente su participación porcentual sobre los ingresos totales de la Real Caja de Buenos Aires ${ }^{10}$ (aun cuando todavía no absorbiera la mayor parte de los ingresos de la caja potosina, como lo haría posteriormente) ${ }^{11}$, mientras la ciudad pasa a constituirse como sede de una nueva configuración política y jurisdiccional.

Gráfica 1. Participación del Real Situado en el cargo total de la Real Caja de Buenos Aires

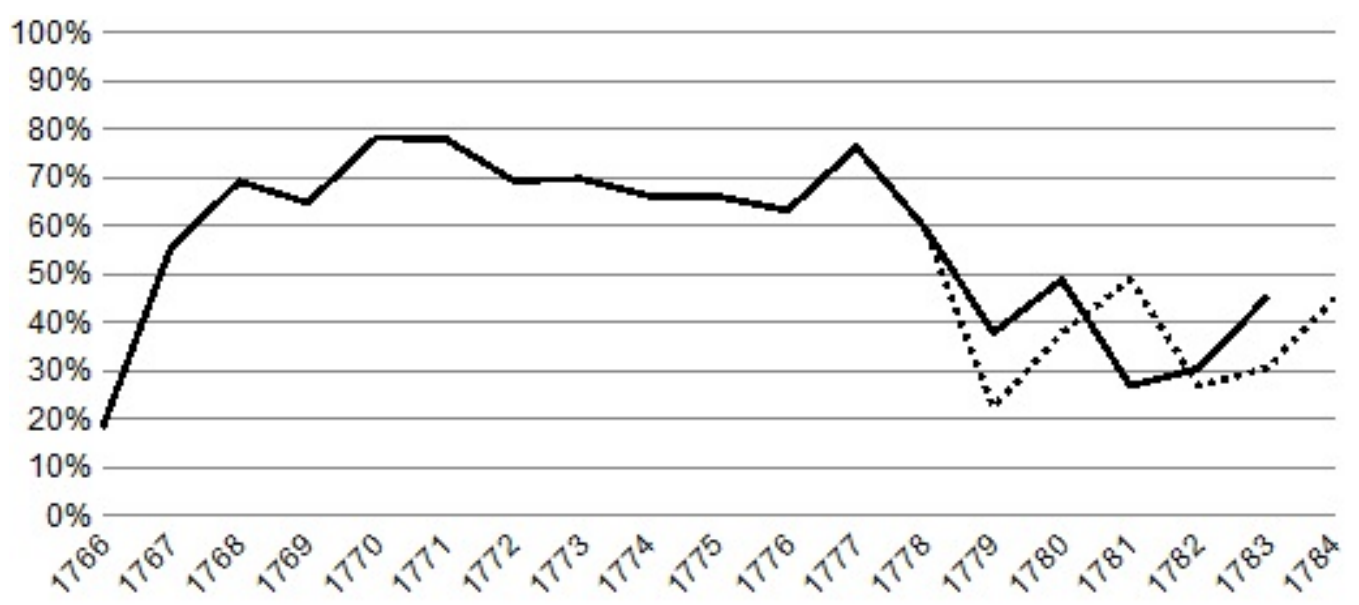

Fuente: Elaboración propia con base en Archivo General de la Nación de la República Argentina (en adelante, AGN), Sala XIII (en adelante, XIII), Libros Principales de Cargo y Data del Ramo de Situados de la Real Caja de Buenos Aires,42-1-20, 42-1-21, 42-1-22, 42-1-23, 42-1-24, 42-1-25; Klein, H. y TePaske, J. (2005 [1982, 1986, 1989]). Nota: Para la estimación se ha relacionado al cargo reportado por los libros principales de cargo y data del ramo, con el cargo anual total reportado por las cartas-cuentas para la Real Caja. Dada la inexistencia de libro del ramo de Situados para 1779, dicha relación se estableció entre la información aportada por las cartas-cuenta.

El protagonismo del Real Situado en el cargo total de la Real Caja porteña es insoslayable ${ }^{12}$. Entre 1766 y 1784 el Real Situado promedió el 55 \% de los ingresos totales a la Caja porteña: estos desembolsos posibilitaron del despliegue económico de Buenos Aires al garantizar su defensa y su consecuente pervivencia en el mapa imperial, lo que vuelve plausible y viable al nuevo Virreinato rioplatense (Tandeter, 1991, p. 201). Gelman y Moraes (2014, p. 72) han advertido, en este sentido, que la

...creación del virreinato y el reforzamiento de todo el sistema defensivo en el Litoral se realiza en gran medida gracias a una fabulosa transferencia de recursos fiscales que llegan desde Potosí a la capital virreinal. Estos recursos sin duda activan fuertemente la demanda local y se convierten así en un factor de crecimiento diferencial que debe ser considerado.

Sin el gasto militar, el resto de la economía no podría haberse mantenido constante ni, consecuentemente, creciente. 


\section{II.2. Las remesas de 1766-1772: la creciente gravitación de un centro fiscal}

La Guerra de los Siete Años había demostrado a la corona española la necesidad de reforzar la defensa de sus territorios, y el frente portugués ameritaba ese refuerzo en el Río de la Plata (Biangardi, 2016). Cuando inicia la confección de los libros del ramo de Situados, en agosto de 1766, la Real Caja de Buenos Aires ya había afrontado los gastos del sitio de Cevallos a Colonia en 1762 (Birolo, 2015, pp. 59, 89; Marchena Fernández, 2014, pp. 20,21). Aquel año la tesorería de Buenos Aires había recibido situados por $\$ 390.000$, suma que representaba el máximo caudal remitido al puerto hasta entonces ,y desde al menos 1674, de acuerdo a la información ofrecida por las cartas-cuenta(Klein y TePaske, 2005 [1982, 1986, 1989]).

Una primera reconfiguración militar enmarcaba todo este proceso: ya no se contaba con la tradicional capacidad para movilizar tropas guaraníes (Quarleri, 2015; Fradkin, 2012), y en 1764 se habían establecido las asambleas en Buenos Aires (unidades de 30 a 40 efectivos rentados por la Real Hacienda) como modo de disciplinar las milicias en una coyuntura que las volvía vitales (Fradkin, 2012, p. 253).

Gráfica II. Ingresos y egresos del Ramo de Situados de Buenos Aires, 1766-1772

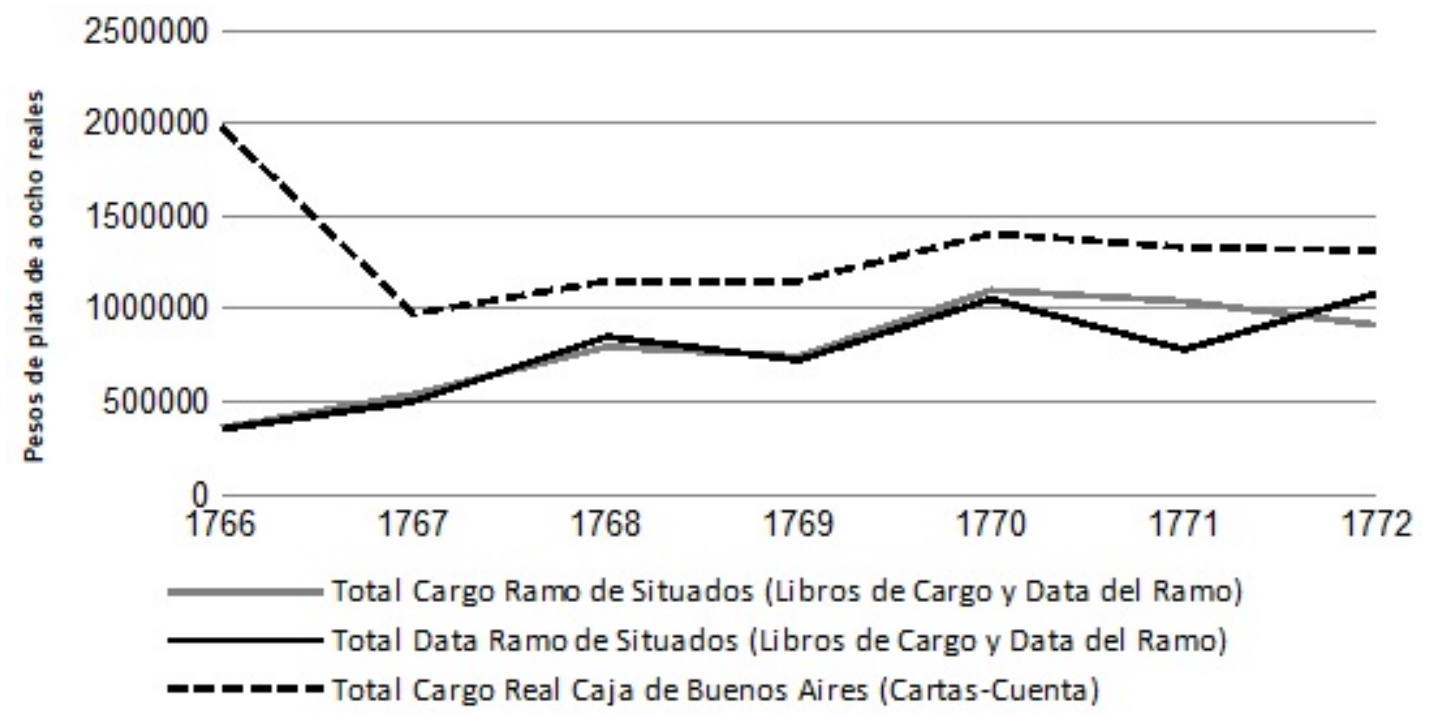

Nota: Las unidades monetarias han sido convertidas al sistema decimal siguiendo la fórmula de Jumar y Sandrín (2015): (donde: $x$ representa pesos, y representa reales, z representa maravedís). La unidad monetaria empleada en el presente artículo está expresada en pesos de plata de a ocho reales.

Si tenemos estos antecedentes en consideración y observamos la información provista por los libros de cargo y data del ramo de Situados,las sumas anuales ingresadas por dicho concepto en la Real Caja porteña sólo atraviesan los $\$ 500.000$ a partir de 1767 (véase la Gráfica II), como respuesta a múltiples factores: en octubre de 1766 el gobernador Bucarelli había enviado medidas preventivas al comandante de la frontera de Río Grande contra la vulneración portuguesa sobre territorio reclamado por España (Marchena Fernández, 2014, pp. 21 y ss.); en 1767 se ponía en marcha el extrañamiento de la Compañía de Jesús, motivado por la Real Pragmática de ese año (Millé, 1972, pp. 286 y ss.); entre tanto, comenzaban las expediciones franco-españolas a Islas Malvinas para disputar el territorio austral a Inglaterra, con bases en Buenos Aires y Montevideo ${ }^{13}$. Todo ello implicó la creciente gravitación de Buenos Aires como centro receptor y redistribuidor de recursos fiscales, así como un reconocimiento institucional de esa gravitación: en 1767 se promulgaba la Contaduría Mayor de Buenos Aires, con alcance jurisdiccional sobre las gobernaciones de Río de la Plata, Paraguay y Tucumán (provincias que dejaban entonces de rendir cuentas a Lima, para pasar a hacerlo ante Buenos Aires) ${ }^{14}$. Este primer incremento del Situado hacia 1767 responde, por lo tanto, a la conjugación entre la dinámica militar y las concomitantes reformulaciones institucionales ${ }^{15}$. Y los recursos 
del Situado retroalimentarían las modulaciones del aparato defensivo bonaerense: en 1772 se constituirían los regimientos fijos de Infantería y Dragones, y se ampliarían los regimientos de veteranos permanentes (Fradkin, 2012, p. 253).

Esta creciente gravitación de Buenos Aires, traducida en la evolución de las remesas que por vía del Real Situado eran conducidas hacia el puerto, no sólo expresa la posición estratégica que militarmente detentaba el puerto; también expresa, correlativamente, un lento proceso de centralización que se iba traduciendo institucionalmente mediante la adecuación del organigrama de la Real Hacienda al peso específico del margen bonaerense en el mapa imperial. La administración del desembolso de los recursos de este ramo primordial en las finanzas reales del Río de la Plata permitirán, por lo tanto, evaluar de qué manera era gestionada la Hacienda y en qué medida esa creciente gravitación tenía o no puntos de encuentro con las tradicionales prácticas de negociación e intermediación de los actores particulares y corporativos.

\section{La distribución de los recursos del Real Situado de Buenos Aires entre 1766 Y 1772}

Mientras que los \$5.485.532,43 ingresados en el libro de Situados entre agosto de 1766 y diciembre de 1772 fueron gestionados mediante 102 partidas de cargo (Wasserman, 2017), los \$5.338.169,47 que fueron desembolsados del mismo ramo durante dicho período requirieron el asiento de 815 partidas de data, lo que evidencia no sólo una distribución capilar de los recursos ingresados a Buenos Aires por la vía del Situado, sino también una gestión contable cualitativamente diferente de la implicada en la administración de los ingresos. Una aproximación a la distribución de esos recursos permitirá comprender más cabalmente los mecanismos implicados en esa administración contable.

\section{III.a. La distribución regional de los recursos del Situado de Buenos Aires}

En primera instancia, es sabido que los recursos del Real Situado de Buenos Aires permanecían sólo parcialmente en la ciudad, en la medida en que porciones variables del mismo eran redistribuidas interregionalmente por los oficiales reales de la Caja porteña, en un esquema del que participaban los principales puntos receptores del Situado en Hispanoamérica (Marichal y Souto, 2012; Pacheco Díaz, 2012). En términos globales - con datos provistos por Halperín Donghi-, Cuesta (2009, p. 132) sugiere que a finales del siglo XVIII (1791-1795) sólo el 28 \% de los gastos totales de la Real Caja de Buenos Aires era desembolsado localmente, mientras que un $33 \%$ se habría enviado a la península y el restante $39 \%$ habría sido aplicado en gastos militares para el despliegue de la frontera (Islas Malvinas, Patagonia, Paraguay, expediciones militares). No obstante, las erogaciones del Situado durante los años que abordamos en el presente estudio (1766-1772) no conllevaron una redistribución interregional tan acusada como la que podría llegar a constatarse décadas más tarde. 
Tabla I. Distribución geográfica del Real Situado recibido por la Real Caja de Buenos Aires (1766-1772)

\begin{tabular}{|c|c|c|}
\hline Destino del desembolso & Suma & $\%$ \\
\hline Buenos Aires & 3968437,189 & $74,3408 \%$ \\
\hline Islas Malvinas y Patagonia & 521833,875 & $9,7755 \%$ \\
\hline Banda Oriental & 458761,8451 & $8,5940 \%$ \\
\hline Brasil & 153820,3125 & $2,8815 \%$ \\
\hline Misiones & 140975,011 & $2,6409 \%$ \\
\hline Transferencia & 64693,64213 & $1,2119 \%$ \\
\hline Lima & 26306,125 & $0,4928 \%$ \\
\hline Ultramar & 3319,46875 & $0,0622 \%$ \\
\hline Cordoba & 22 & $0,0004 \%$ \\
\hline Total & 5338169,469 & $100 \%$ \\
\hline
\end{tabular}

Fuente: elaboración propia con base en AGN, XIII, 42-1-20 y 42-1-21.

En efecto, entre 1766 y 1772 más del 74 \% de los recursos del Situado (que llegó a constituir cerca del $80 \%$ de los ingresos de la Real Caja porteña) era desembolsado en Buenos Aires. Entre tanto, cerca del $10 \%$ de dichos recursos fue destinado a las expediciones y al establecimiento español de Islas Malvinas, lo que cubría al menos el $84 \%$ de los $\$ 618.024$, que otro documento testimonia que fueron devengados entre 1767 y 1769 en la empresa malvinense ${ }^{16}$. A su vez, algo más del $11 \%$ de los recursos del Situado fueron destinados al frente portugués (la banda oriental del Río de la Plata $-8,6 \%$ - y distintos puntos del Brasil -casi $3 \%-)$. Y es comprensible que el 2,65\% de los recursos del Situado durante estos años haya tenido a Misiones por destino: el extrañamiento de la Compañía de Jesús tendría lugar a partir de $1767^{17}$ , y otro documento del período indica que en 1767 los gastos causados en Misiones habrían ascendido a unos $\$ 100.000$ estimados ${ }^{18}$. En concordancia, los libros del Real Situado permiten comprender que entre 1767 y 1772 fueron desembolsados de este ramo al menos \$140.975, lo que cubría y reintegraba los gastos devengados en dicha empresa y derivados de la misma.

No obstante, los asientos contables omiten mediaciones geográficas necesarias en la circulación fiscal de estas redistribuciones regionales del Situado. Es claro que el grueso de los recursos destinados por Buenos Aires a Islas Malvinas (y a la Patagonia atlántica en general) pasaba por Montevideo, que venía erigiéndose como apostadero naval para la comunicación con la frontera austral de la Monarquía en América, razón por la cual la participación de Montevideo se ve subrepresentada en la contabilidad fiscal como localidad receptora del Situado redistribuido por Buenos Aires ${ }^{19}$. De igual forma, no todos los desembolsos realizados en Buenos Aires iban a manos de receptores con asentamiento estable en la ciudad o en su campaña, pero de todos modos resultaba habitual que ello se registrase en las partidas contables (lo que disminuía ese margen de omisiones en la especificación geográfica del gasto) ${ }^{20}$. 


\section{III.b. Las finalidades de las erogaciones del Situado}

En función de lo antedicho, los sueldos de tropas y oficiales de diferentes unidades militares, veteranas y milicias, adquirieron primacía en la distribución de los recursos del Situado (casi $58 \%$ de las erogaciones). Si los gastos implicados en expediciones y en la erección de fortificaciones tuvieron un lugar relevante (más del $10 \%$ ), la utilización de estos recursos para el pago de proveedores y de acreedores de la Hacienda Real en Buenos Aires (que ascienden en conjunto a más de $26 \%$ de los fondos) se posicionan como un renglón explicativo sobre el modo en que eran administrados los recursos del erario.

Tabla II. Finalidad de la distribución de recursos del Real Situado de Buenos Aires (1766-1772)

\begin{tabular}{|l|l|l|}
\hline \multicolumn{2}{|l}{ Tabla II. Finalidad de la distribución de recursos del Real Situado de Buenos Aires (1766-1772) } \\
\hline Rótulos de fila & $\%$ & Suma \\
\hline Sueldos de tropas y oficiales & $57,84 \%$ & 3087598,89 \\
\hline Pago a proveedores & $19,46 \%$ & 1038695,12 \\
\hline Gastos de expediciones y fortificaciones & $10,13 \%$ & 540593,13 \\
\hline Pago a acreedores & $6,96 \%$ & 371468,63 \\
\hline Sureldos de militares de alto rango & $2,95 \%$ & 157706,78 \\
\hline Trans ferencia a otros ramos contables & $1,82 \%$ & 97380,14 \\
\hline Sueldos y jornales no militares & $0,73 \%$ & 38991,86 \\
\hline Gastos eclesiásticos y capellanias & $0,06 \%$ & 3269,13 \\
\hline Pago a viudas y derechohabientes & $0,04 \%$ & 2357,63 \\
\hline Gastos administrativos de la Real Hacienda & $0,00 \%$ & 108,19 \\
\hline Total & $\mathbf{1 0 0 , 0 0 \%}$ & $\mathbf{5 3 3 8 1 6 9 , 4 7}$ \\
\hline Fuente: elaboración propia con base en AGN, XII, 42-1-20 y 42-1-21. & & \\
\hline
\end{tabular}

Fuente: elaboración propia con base en AGN, XIII, 42-1-20 y 42-1-21.

\section{III.b.1. Sueldos militares: desigualdades y demoras}

Las unidades de tropas veteranas eran concebidas, tanto en Buenos Aires como en el resto de Hispanoamérica, como cabeza o núcleo de la defensa, pero no como su cuerpo principal. Éste estaba dotado, entre tanto, por unas milicias reclutadas localmente y ampliamente superiores en número (Beverina, 1992 [1935], p. 198; Kuethe, 2007). En efecto, los cuerpos veteranos en Buenos Aires ascendían en 1771 a unos 3.100 efectivos $^{21}$, a los que habría que sumar cerca de unas 200 personas involucradas como Blandengues (los cuales pasarían a transformarse en un cuerpo veterano de caballería en 1784). Pero las milicias en la ciudad y en la campaña bonaerense reportaban unas 5.300 personas, junto a las cuales podrían considerarse los más de 3.000 efectivos dispuestos en las milicias de Santa Fe, Corrientes y distintos puntos de la banda oriental del río, como Montevideo o Santo Domingo Soriano ${ }^{22}$.

Esas milicias locales, que irían complejizando su organización en la ciudad pero también en la campaña, se volvían necesarias ante una recurrente deserción en las filas veteranas. La consecuente necesidad de disciplinar a unas milicias que resultaban vitales en estas coyunturas conflictivas condujo en 1764 al establecimiento 
de las asambleas: unidades de unos cuarenta efectivos veteranos, rentados por la Hacienda Real, para el adiestramiento militar y disciplinamiento de las milicias (Fradkin, 2012) ${ }^{23}$.

Estas reformulaciones en las fuerzas defensivas, y la exposición de Buenos Aires a los conflictos imperiales, llevaron a la Corona a ordenar al virrey Amat y a los oficiales de la Real Caja de Potosí que habilitasen a los oficiales de Buenos Aires los caudales que éstos requiriesen (Kuethe, 2005, p. 114). Ello formaba parte de una reconfiguración más amplia y de orden sistémico: hacia el siglo XVIII, el gobierno borbónico actualizó las guarniciones de presidio para transformarlas en ejército regular, organizándolo en compañías, regimientos y batallones, con jerarquías definidas y estructuradas en planas mayores (Birolo, 2015: 34; Fradkin, 2012). En Buenos Aires, durante el período que abordamos, ejemplifican esta reorganización los regimientos de Mallorca y de Dragones, los batallones Antiguo y Moderno de Buenos Aires - fundado por Bucarelli- o el batallón de Santa Fe. Hacia enero de 1768, por ejemplo, existían ocho cuerpos veteranos sirviendo en la plaza de Buenos Aires que recibían dineros del Situado: el Regimiento de Dragones Antiguos, el Batallón de Infantería de Buenos Aires (organizado en Moderno y Antiguo), el Cuerpo de Artillería, el Batallón de Santa Fe, el Regimiento de Infantería de Mallorca, y las asambleas de Caballería, Dragones e Infantería. En 1771 dos Reales Órdenes disponían la reorganización de las unidades veteranas: éstas pasarían a constituirse con un regimiento de infantería ("de Buenos Aires", que absorbía al Antiguo, al Moderno y al de Santa Fe), otro de Dragones (que absorbería al regimiento de infantería de Mallorca e incorporaría al regimiento de voluntarios de Cataluña, el cual aparece en escena en 1771) y una compañía de Artillería. De esta manera, en abril de 1772 el gobernador Vértiz informaba la extinción de los batallones Antiguo, Moderno y de Santa Fe, y la formación de los dos regimientos de Infantería y Dragones, así como de la Compañía de Artillería (Beverina, 1992 [1935], pp. 200-201) ${ }^{24}$.

Tabla III. Distribución de sueldos militares por unidad receptora. Real Situado de Buenos Aires (1766-1772)

\begin{tabular}{|c|c|c|}
\hline \multicolumn{3}{|c|}{$\begin{array}{l}\text { Tabla III. Distribución de sueldos milita } \\
\text { Real Situado de Buenos Aires (1766-1772) }\end{array}$} \\
\hline Unidad & Suma & $\%$ \\
\hline Uniclades veteranas & 2677867,24 & $82,52 \%$ \\
\hline Milicias y blandengures & 240127,64 & $7,40 \%$ \\
\hline Asambleas & 173142,31 & $5,34 \%$ \\
\hline Real Armada & 73220,48 & $2,26 \%$ \\
\hline Inválidos & 59654,69 & $1,84 \%$ \\
\hline Real Hacienda, Gobernador, Correos & 14390,00 & $0,44 \%$ \\
\hline Apoderados y derechohabientes & 5638,31 & $0,17 \%$ \\
\hline Otros & 1265,00 & $0,04 \%$ \\
\hline Total & 3245305,662 & $100,00 \%$ \\
\hline
\end{tabular}

Fuente: elaboración propia con base en AGN, XIII, 42-1-20 y 42-1-21.

Como puede observarse, los recursos destinados al pago de sueldos de estas tropas y sus oficiales más los aplicados a militares de alto rango (tales como los pertenecientes a las planas mayores) ascendieron a casi $61 \%$ del total de fondos del Situado entre 1766-1772. La distribución de los mismos tuvo por claras protagonistas a las unidades veteranas, muy de lejos seguidas por los cuerpos de milicias (el detalle de las 
fuerzas que constituían cada segmento puede apreciarse en el Apéndice I). Dadas las estimaciones de efectivos disponibles en cada fuerza, es visible que las unidades veteranas representaban el $36 \%$ de los efectivos de los que la Corona disponía para la defensa y obtenían el 82,52 \% de los sueldos militares desembolsados por el Real Situado, mientras que las milicias y los blandengues (que aún no constituían cuerpos veteranos) representaban el $64 \%$ de los efectivos, pero sólo se les otorgaba el 7,40 \% de los sueldos militares del ramo del Situado.

Tabla IV. Unidades veteranas y milicias. Ponderación de sueldos en relación a efectivos

\begin{tabular}{|c|c|c|c|c|}
\hline \multicolumn{5}{|c|}{$\begin{array}{l}\text { Tabla IV. Unidades veteranas y milicias. Ponderación de sueldos en relación a } \\
\text { efectivos }\end{array}$} \\
\hline Unidades & $\begin{array}{l}\text { Suma de } \\
\text { Efectivos }\end{array}$ & $\%$ Efectivos & $\begin{array}{l}\text { Sueldos } \\
\text { recibidos del } \\
\text { Situado }\end{array}$ & $\begin{array}{l}\% \text { de streldos } \\
\text { recibidos del } \\
\text { Situado }\end{array}$ \\
\hline Milicias y Blandengues & 5613 & $64 \%$ & 240127,64 & $7,40 \%$ \\
\hline Veteranos & 3151 & $36 \%$ & 2677867,24 & $82,52 \%$ \\
\hline \multicolumn{5}{|c|}{$\begin{array}{l}\text { Fuente: elaboración propia con base en AGN, XIII, 42-1-20 y 42-1-21; Alemano (2016); } \\
\text { Beverina (1992 [1935]). }\end{array}$} \\
\hline
\end{tabular}

Fuente: elaboración propia con base en AGN, XIII, 42-1-20 y 42-1-21; Alemano (2016); Beverina (1992 [1935]).

Esta desigualdad en la distribución de los recursos para sueldos militares tiene explicación, al menos en parte, en la política que la Corona desplegaba en la frontera rioplatense. Como lo señalase recientemente Alemano, la frontera que la Corona tenía en consideración en el Río de la Plata era, primordialmente, la portuguesa (y, durante la primera mitad de la década de 1750, la guaranítica). En contraste con la conflictividad araucana de largo plazo en el caso chileno, la frontera indígena en el Río de la Plata no ameritaba para el Erario regio el desembolso de recursos orientados a ese fin (Alemano, 2016, pp. 133 y ss.) ${ }^{25}$. El Real Situado atendía consecuentemente a la frontera atlántica y, por extensión, a la puerta fluvial del Río de la Plata $^{26}$.

Ante la relativa desatención de la Corona sobre la frontera indígena, hacia 1752 el Cabildo de Buenos Aires crearía tres compañías de blandengues y comenzaría a recaudar fondos mediante un novedoso "Ramo de Guerra" para sostenerlas. Con ello creó una verdadera estructura fiscal que encauzaba recursos a la jurisdicción rural bonaerense con la agencia del Cabildo, dada la insuficiencia de fondos que la Real Hacienda alegaba experimentar para financiar la defensa de la frontera (Fradkin, 2012, p. 252; Alemano, 2016, cap. 2). Fernando VI identificó claramente una vulneración de su capacidad impositiva y desautorizó la administración capitular de aquel nuevo Ramo, sin embargo, el lado anverso de este fenómeno consistía en que las compañías de frontera interna no implicaban erogaciones a la Hacienda Real. Ello experimentaría un giro cuando en 1761, como expresión del proceso de concentración de poder gubernamental durante la administración de Cevallos, el Ramo de Guerra pasase de la órbita del Cabildo a manos de la Real Hacienda: este arrebatamiento institucional respondía a las deudas que el Cabildo había acumulado con las milicias por expediciones como la de las Salinas (1759), resultantes de la insuficiencia en la recaudación capitular de aquel ramo $^{27}$.

Puesto que los efectivos movilizados para la frontera indígena no estaban percibiendo sueldos del vapuleado Ramo de Guerra, el gobernador Cevallos liberó en 1762 "fondos del «situado» extraordinario enviado para la expedición a Colonia del Sacramento", con el objeto de sostener mediante los fondos del Situado a las compañías de frontera. El dinero así erogado del Situado para la frontera indígena debía sin embargo reintegrarse al cargo del Situado con los fondos que recaudase el Ramo de Guerra (Alemano, 2016, p. 
52). No obstante, el estudio sobre la gestión del Ramo de Guerra bajo la Hacienda Real demuestra que dicho ramo dejó de ser deficitario, para volverse superavitario desde 1772, puesto que su recaudación aumentó con el incremento del comercio de cueros (principal base imponible del impuesto que nutría al ramo), a la vez que se disminuyeron los gastos asignados a dicho Ramo de Guerra (en la medida en que Bucareli había ordenado en 1770 la disminución de efectivos ante el déficit heredado de la gestión capitular). Esta novedosa condición superavitaria del Ramo de Guerra condujo a los oficiales reales a invertir el flujo de fondos: ahora comenzarían a enviar recursos del Ramo de Guerra al Ramo del Situado, alegando que éste no llegaba a Buenos Aires. A partir de ello puede asumirse que los recursos del Ramo de Guerra no habrían sido asignados a la defensa de la frontera indígena, sino aplicados a la financiación de un Situado que debería solventar los demás gastos militares pero que -alegaban los oficiales reales- no llegaba: sobre este aspecto hemos demostrado la efectiva llegada del Situado, aún con demoras. De este modo, el Ramo de Guerra pasaba a ser, paradójicamente, "financista" del Situado (Alemano, 2016, p. 54). En efecto, y tal como pudo demostrarse en otro trabajo (Wasserman, 2017) el Ramo de Guerra aportó al ramo de Situados $\$ 43.000$ en 1772, \$30.000 en 1773 y $\$ 40.000$ en 1774 (otros $\$ 193$ serían reportados en 1778 , como reintegro del salario de alférez) ${ }^{28}$. Ello asimismo puede explicar, al menos en parte, el modo en que era cubierta la diferencia existente entre ingresos y desembolsos del ramo de Situados en 1771.

Tal como ha sido descripto en otra ocasión, el $87 \%$ de los ingresos al cargo del ramo de Situados de Buenos Aires consistió en la remisión de caudales (Wasserman, 2017). Las modalidades bajo las cuales se desenvolvían esos envíos pueden distinguirse en tres: el Real Situado propiamente dicho, de envío en principio ordinario y regular; remisiones de otras cajas(transferencias realizadas desde otras Reales Cajas por fuera del conducto del Situado, aun cuando dichas remisiones se registraran contablemente en el cargo del libro de Situados), y socorros extraordinarios. Estos últimos constituían remisiones de caudales que se suponían ocasionales, aunque enviadas mediante el mismo conducto que el situado ordinario, para hacer frente a gastos no previstos en el presupuesto. Pero su naturaleza extraordinaria pasaría a regularizarse en cuanto a frecuencia y cantidades (Marchena, 2001, pp. 619-620).

Estas inyecciones de caudales al cargo del Situado, que eran complementadas con otras formas de ingresos patrimoniales o financieros a dicho ramo (transferencias destre otros rubros y rentas, reintegros, retenciones de derechos y beneficios del cambio monetario), marcaban el ritmo y las modalidades del pago a las tropas y a la oficialidad: 02 
Gráfica III. Pagos a efectivos militares discriminados por modalidad de liquidación. Real Situado de Buenos Aires (1766-1772)

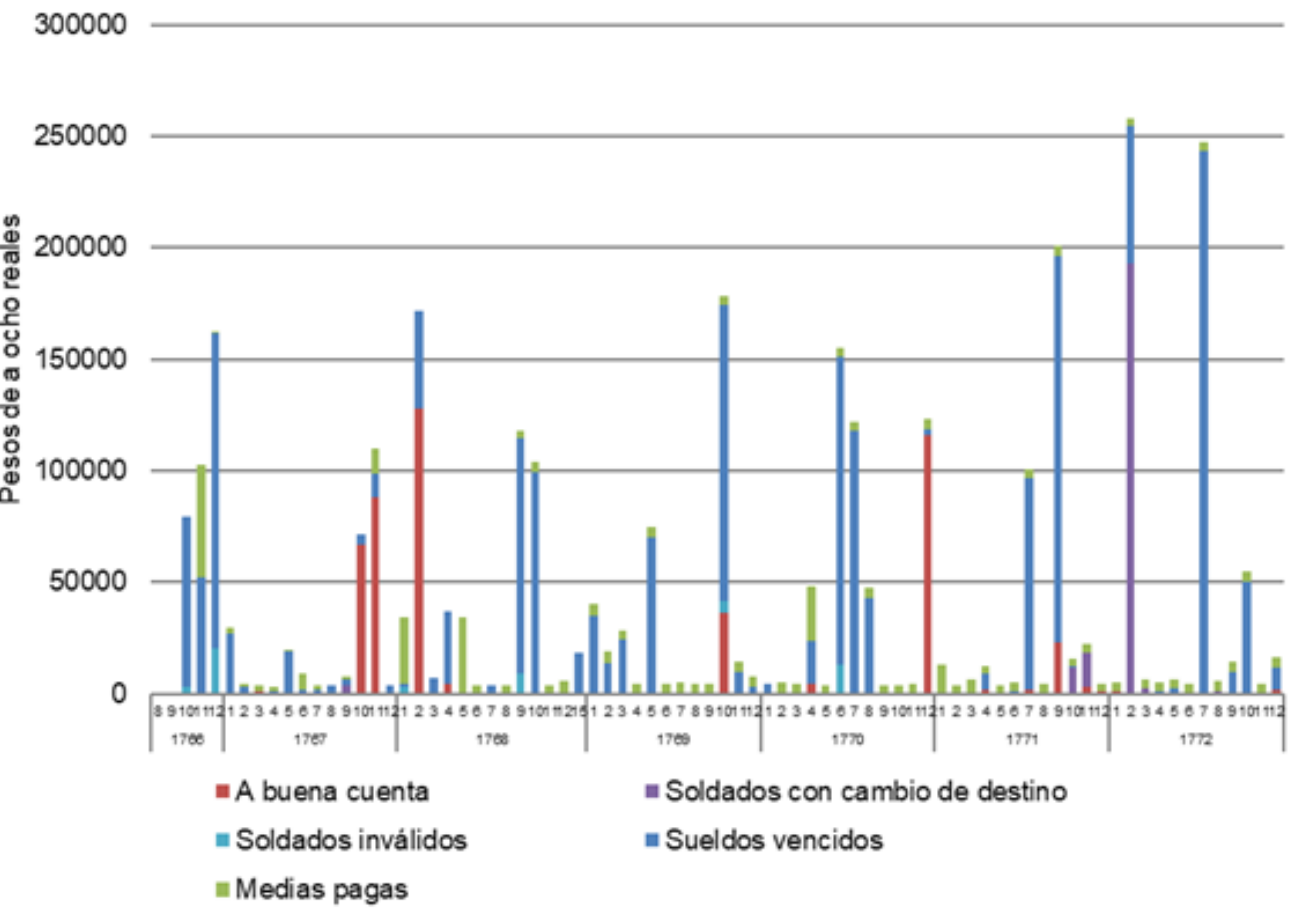

Fuente: elaboración propia con base en AGN, XIII, 42-1-20 y 42-1-21.

Precisamente, a pesar de constituirse formalmente como una figura extraordinaria, los socorros constituían el pago corriente de mayor regularidad (mensual), y ascendían a importes equivalentes a la "media paga" del mes en curso, lo cual implicaba el desembolso de bajos recursos mediante un goteo regular. Entre tanto, los pagos "a buena cuenta" conformaban otro renglón en el desembolso a las tropas, la oficialidad y militares de altos rangos. Al igual que las "medias pagas", los anticipos entregados "a buena cuenta" se descontaban al momento de liquidarse los haberes por "sueldos vencidos": rubro mediante el cual solían liquidarse partidas más grandes que las medias pagas, así como los grandes desembolsos realizados con menor frecuencia una vez arribados los caudales a la ciudad, cuyo ingreso al cargo del ramo permitía a los oficiales reales saldar la deuda que la Hacienda sostenía con los efectivos (véase Gráfica).

Sargentos mayores, ayudantes mayores, tenientes, capitanes y comandantes eran quienes, bajo la figura de apoderados o habilitados por sus cuerpos, solían presentarse a recibir los fondos del Real Situado para redistribuir entre los efectivos de las unidades. En algunos casos no quedaba asentada la identidad personal del receptor en la partida (como cuando se asentaba que "damos en data quatro mil seiscientos quarenta y quatro pesos dos reales pagados a los ocho cuerpos de tropa de esta plaza", sin especificar en manos de quiénes sería depositado el caudal ${ }^{29}$, pero la identidad del apoderado o habilitado que recibía los sueldos quedaba regularmente explicitada en el asiento contable (en el Apéndice II puede conocerse la nómina de habilitados que cada cuerpo tenía para recibir los fondos del Situado destinados a sueldos entre 1766 y 1772).

Si bien actualmente se encuentra en curso un trabajo de investigación para la reconstrucción de las redes interpersonales que enlazaban a estos actores con comerciantes, mercaderes y oficiales reales ${ }^{30}$, los avances historiográficos con que contamos sugieren que estos sujetos -formalmente habilitados para tomar de la Real Caja los caudales destinados a sueldos de aquellas tropas a las que representaban- eran empleados por las redes a las que pertenecían para distribuir parte de esos fondos entre mercaderes, comerciantes y altos 
rangos militares, como reintegro al crédito mercantil que éstos habían facilitado a las tropas ante las urgencias generadas por las demoras y retrasos en el pago de sueldos ${ }^{31}$.

Las demoras en la llegada del Situado quedan de esta manera evidenciadas en la morosidad que la Hacienda real sostenía con los efectivos por la paga de sus "sueldos vencidos", mora habitualmente declarada en la liquidación de los mismos. Los sueldos que eran así abonados correspondían a rangos concretos de tiempo trabajado (por ejemplo, seis meses de trabajo realizados entre distintas fechas), con una dilación variable en la paga (pues el retraso en el pago por ese rango de tiempo trabajado podía realizarse, por ejemplo, un año después de que hubiese finalizado dicho trabajo).

Gráfica IV. Morosidad de la Hacienda real en el pago de sueldos vencidos (promedios). Real Situado de Buenos Aires, 1768-1772

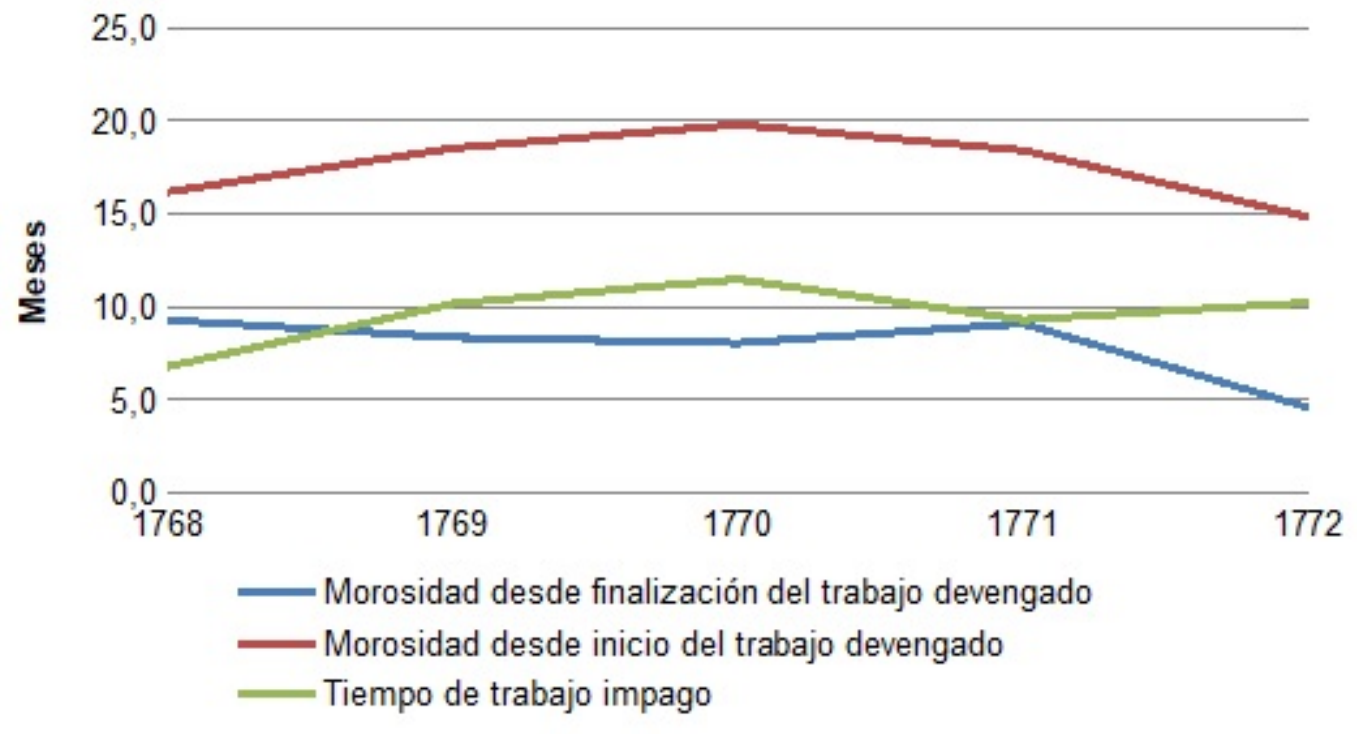

Fuente: elaboración propia con base en AGN, XIII, 42-1-20 y 42-1-21.

Dada la naturaleza cambiante de la información provista por los documentos del ramo a lo largo de los años aquí analizados, contamos con la posibilidad de calcular la morosidad implicada en el pago de los sueldos vencidos entre 1768 y 1772. Se aprecia, en este sentido, que durante estos años era regular que el pago de los sueldos se demorase 7,9 meses desde la fecha en que había finalizado el trabajo devengado. Este plazo se extiende a 17,6 meses si se computa desde el inicio del trabajo impago. El tiempo trabajado impago promedia entretanto los 9,6 meses. También puede observarse que allí cuando se incrementaba el tiempo de trabajo impago, los oficiales reales procuraban disminuir la morosidad de la paga (se advierte en 1770 y en 1772), quizás con miras a no acumular deudas que redundasen en mayores deserciones. 
Gráfica V. Demora en las pagas con recursos del Real Situado (promedios). Buenos Aires, 1768-1772

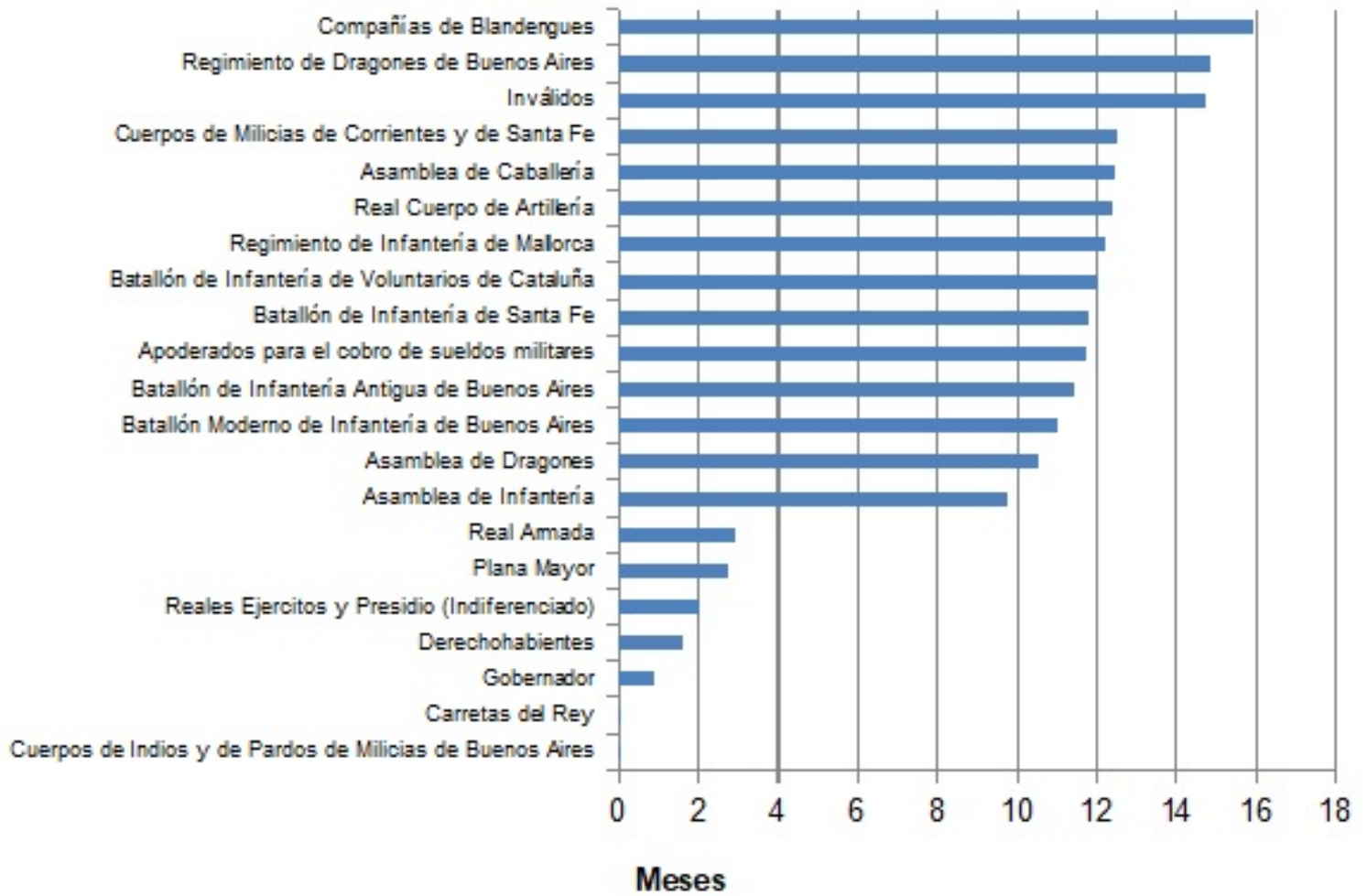

Fuente: elaboración propia con base en AGN, XIII, 42-1-20 y 42-1-21.

Al evaluar las demoras en las pagas por los distintos cuerpos y unidades receptoras, es claro que la compañía de Blandengues también en este aspecto quedaba relegada en relación al desembolso de recursos del Situado, ya que promediaba los 16 meses de demora en la liquidación de sus remuneraciones. Si los Dragones y el cuerpo de Inválidos la secundaban, debe advertirse que los cuerpos de milicias de Corrientes y de Santa Fe también quedaban habitualmente relegados. No obstante, y pese a estas diferencias en el tratamiento de los cuerpos a la hora de priorizar la liquidación de sus respectivos sueldos, prácticamente todas las unidades, veteranas y milicianas, experimentaban retrasos en sus pagos de entre 10 meses y un año. Que los retrasos en el pago a la Plana Mayor promediasen los 2,7 meses es indicativo de la discrecionalidad que marcaba el ritmo de los desembolsos del Situado para pagas de remuneraciones, inequidad que se suma a las ya mencionadas desigualdades en la distribución de sus recursos.

Al considerar estas desproporciones en los tiempos de liquidación y en la distribución de recursos, es crucial advertir asimismo que, al momento de realizarse el pago de los haberes, los sueldos vencidos experimentaban el descuento de anticipos, buenas cuentas y socorros abonados con anterioridad a la liquidación. Por caso, el 3 de julio de 1771 don Miguel Sandier, teniente y habilitado del Batallón de Infantería Moderna de Buenos Aires, recibía \$14.152 "por resto del haver venzido por los individuos del Regimiento de Dragones de Buenos Ayres en los seis ultimos meses del año pasado de mil setezientos sesenta y nuebe". En dicha ocasión se aclaraba que quedaban "descontados los socorros y buena quenta del año de setenta" 32 . Expresión condensada de lo antedicho: todo un regimiento (calculado en unos 507 efectivos) recibía en 1771 la paga por los servicios prestados durante el segundo semestre de 1769 (esto es, devengados dos años antes). Si ello explica las frecuentes deserciones que acicateaban la importancia de reglar unas milicias cada vez más necesarias, la permanencia de quienes mantenían su desempeño en las filas del regimiento se explica -al menos en parte- por esos socoros y pagas a buena cuenta, desembolsadas en el año intermedio, que ahora se descontaban en la liquidación de los sueldos vencidos. El rol de los acreedores de la Hacienda Real resulta, 
por lo tanto, fundamental para comprender la administración de estos recursos protagónicos para el Erario regio en Buenos Aires.

\section{III.b.2. Proveedores y acreedores: protagonistas locales de una Hacienda endeudada}

Tal como se observara anteriormente, los desembolsos orientados al pago de acreedores y proveedores de la Hacienda Real en Buenos Aires ascendieron en conjunto a más de $26 \%$ de los fondos distribuidos localmente por el ramo de Situados. Tales recursos satisfacían pagos y reintegros por motivos heterogéneos, encabezados por la provisión de víveres y el anticipo de dinero para suplir gastos vinculados al funcionamiento de la maquinaria defensiva (en el Apéndice III se podrá observar la nómina completa de acreedores y proveedores, y los motivos por los que cada uno recibía su reintegro).

Tabla V. Motivos de reintegro a acreedores y proveedores. Real Situado de Buenos Aires (1766-1772)

\begin{tabular}{|l|l|l|}
\hline Tabla V. Motivos de reintegro a acreedores y proveedores. Real Situado de Buenos Aires (1766- \\
1772) & Suma & $\%$ \\
\hline Motivo del reintegro & 604927,8 & $42,9 \%$ \\
\hline Viveres & 356709,8 & $25,3 \%$ \\
\hline Suplemento monetario & 272864,4 & $19,3 \%$ \\
\hline Materiales para mantenimiento y habilitación de embarcaciones & 100732,7 & $7,1 \%$ \\
\hline Materiales para mantenimiento de establecimientos y expediciones & 42286,7 & $3,0 \%$ \\
\hline Calballos, mulas, bureyes & 14937,7 & $1,1 \%$ \\
\hline Vestuario & 11377,5 & $0,8 \%$ \\
\hline Medicinas & 4511,8 & $0,3 \%$ \\
\hline Alquileres & 1815,6 & $0,1 \%$ \\
\hline Pólvora, armamento y acondicionamiento de pertrechos & 1410163,7 & $100,0 \%$ \\
\hline Total general & & \\
\hline Fuente: elaboración propia con base en AGN, xII, 42-1-20 y 42-1-21 & \\
\hline
\end{tabular}

Fuente: elaboración propia con base en AGN, XIII, 42-1-20 y 42-1-21

Y si bien unas 97 personas fueron receptoras de recursos del Situado por distintos conceptos vinculados a la provisión o a suplementos, la concentración de estos desembolsos resultó considerablemente más acusada que en la distribución de sueldos. Mientras que casi un $6 \%$ fue reintegrado a "individuos del comercio" que prestaron dinero de manera colectiva en dos ocasiones y un $8 \%$ fue reembolsado a otros ramos de la Hacienda real por créditos internos en cinco oportunidades, un pequeñísimo grupo de personas concentró buena parte de los repagos. En efecto, Martin de Sarratea, Francisco de San Ginés y Juan Ignacio de Elia embolsaron el 65 $\%$ de estos fondos del Situado en sus arcas personales desde la ventajosa posición que les confería su rol como asentistas de víveres. En este sentido, si bien hay una multitud de actores en la nómina de destinatarios de reembolsos, éstos no concentraron más que el 21,40\% de los recursos desembolsados del ramo de Situados por pago a acreedores y proveedores ${ }^{33}$.

Tal como lo señalase Sandrín (2014), los asentistas de víveres desde luego no circunscribían sus actividades económicas a esa función, la cual participaba de un heterogéneo conjunto de negocios y empresas interrelacionadas de manera diferente y, según el caso, con la provisión contractual dispuesta por el asiento (en efecto, en concordancia con lo señalado por Sandrín, el contrato fomentaba el despliegue de sus propias 
redes de transporte, entre otros negocios concatenados al suministro de víveres). La provisión de alimento y habilitación de embarcaciones, tropas y pasajeros, en efecto, absorbía el grueso de los recursos de la Corona a escala monárquica. Y a lo largo del siglo XVIII fue la modalidad del asientocontratado con particulares, antes que la modalidad de la administración directa, la que predominó como modelo elegido por los Borbones para abastecimiento de víveres (Torres Sánchez, 2016, p. 18).

De esta manera, los asentistas de víveres lograron un posicionamiento privilegiado desde sus contratos de aprovisionamiento a guarniciones y tripulaciones, requiriendo del crédito necesario para afrontar una provisión cuya paga sería reintegrada periódicamente por la Hacienda real. En efecto, la capacidad crediticia del asentista era condicionante: si en la península la forma de pago del suministro se constituía como un eje primordial y conflictivo en la negociación del precio del contrato (Torres Sánchez, 2013, p. 176), en Buenos Aires la Real Caja abonaba periódicamente, con una frecuencia irregular que iba desde pagos cada dos meses (como ocurrió con los reintegros a don Francisco de San Ginés en 1769) hasta pagos mensuales (tal como sucede con los reembolsos a Martín de Sarratea en 1771), lo que hacía que en los hechos el modo de pago al asentista se acercase más a "mesadas" que a "anualidades" 34 .

Francisco de Llano San Ginés era un comerciante y naviero de gran envergadura, cuyos negocios con la Hacienda real encontraron dinamismo en la expulsión de la Compañía de Jesús de la zona de Misiones, ocasión en la cual proveería lanchas, reses vacunas y anticipos para calafates, maestros carpinteros y víveres: el 23,25 \% del costo de la expedición de extrañamiento habría sido aportado de sus fondos, los que redundaría para San Ginés en su nombramiento como administrador general de los pueblos de indios que anteriormente estaban bajo el control jesuítico (Herrero Gil, 2013, pp. 3, 10). No era su primera intervención en el financiamiento de la Hacienda real: durante el gobierno de Cevallos había participado de la rehabilitación del fuerte de Buenos Aires con materiales. Pero el estrecho vínculo de San Ginés con Bucarelli -sucesor en el gobierno de Buenos Aires y con quien retornaría a la Península en 1770 - condujo a rispideces con Cevallos, quien años más tarde escribía como virrey a Gálvez, acusando a Bucarelli de enriquecimiento ilícito e involucrando a San Ginés en ello: "que a mi salida de Buenos Aires era un pobrete, y que fue en su compañía, y le sirvió para sus robos, quinientos mil pesos" (citado por Herrero Gil, 2013, p. 6). De constatación improbable, la acusación de Cevallos permite sin embargo identificar que el contrato de San Ginés como asentista de víveres estaba menos condicionado por su eficiencia en la provisión de pertrechos que por enlaces políticos.

El rol de San Ginés como asentista de víveres le permitía, ya desde 1767, embolsarse cuantiosas sumas al contado, como los más de $\$ 30.000$ "por resto del importe de los viveres remitidos a los puestos de Martin Garcia, Real de San Carlos, Montevideo, Maldonado y Rio Grande para la suscistenca de la tropa que los guarneze" ${ }^{35}$. Y buena parte de estos pagos los obtenía en moneda doble, a diferencia del pago recibido por la mayoría de las tropas en calidad de sueldos (y en contraste, también, con muchos otros proveedores y acreedores ocasionales de la Hacienda) ${ }^{36}$. Desde la provisión de velas de sebo ${ }^{37}$, vestuario ${ }^{38}$ y pertrechos para embarcaciones de las expediciones a Islas Malvinas ${ }^{39}$, hasta anticipos para la construcción de estacadas de palo para el Real Bloqueo de San Carlos con el cual "estorbar el comercio ilícito de la Colonia del Sacramento" ${ }^{40}$, San Ginés encontró instancias en las cuales capitalizar parte de sus fondos en el Real Servicio. Y su vínculo con Buenos Aires no finalizaría con su regreso a los reinos de España: en 1778 San Ginés despachaba un buque desde Cádiz, ocasión en la que Agüero procuraba desde las costas rioplatenses importar ropas, ante el cambio de reglamento comercial y la modificación de gravámenes (Schlez, 2013, p. 276).

Juan Ignacio de Elía había nacido en Pamplona y, ya en Buenos Aires, casaría en 1766 con doña María Bárbara García de Zúñiga (Pardo de Guevara y Valdés, 2015, p. 835). El matrimonio consolidaba su inserción en una red de solidaridades, enmarcada en la pertenencia a los altos rangos de las milicias rurales. Tal como lo identificase Mayo (1987) y lo resaltase Saguier (2004/2007), este enlace lo posicionaba como cuñado del comandante del batallón de milicias, Juan Francisco García de Zúñiga, un poderoso terrateniente en las dos 
orillas del río Uruguay, a la vez que lo volvía concuñado de los coroneles Manuel Antonio Warnes y José María Calceite.

Elía se encontraba, ya desde diciembre de 1769, proveyendo a los navíos de la Real Armada en Buenos Aires, "por via de asignación" y "en virtud de contrata" celebrada con los oficiales de la Real Caja de Buenos Aires, en razón de lo cual embolsaba la elevada suma de $\$ 25.000^{41}$. A la provisión de víveres y materiales para la habilitación y pertrechos de navíos, sumaba el suministro "colchones, mantas y otros utiles subministrados para el quartel de las dos compañias de granaderos del regimiento de Infanteria de Mallorca” ${ }^{42}$ y la provisión de madera para "fortalecer los puertos de Montevideo, Maldonado, Santa Theresa y Rio Grande” ${ }^{43}$, así como suplementos monetarios ${ }^{44}$.

Martín de Sarratea era guipuzcoano, y en Buenos Aires formaba parte de una red involucrada en acusaciones de contrabando, en la cual participaban nada más ni nada menos que los oficiales de la Real Hacienda: el factor Martín de Altolaguirre, el tesorero Pedro de Medrano y el contador Juan de Bustinaga, administradores de las finanzas reales en la Caja de Buenos Aires ${ }^{45}$. A comienzos de 1750, Sarratea había sido nombrado tesorero real de las fuerzas militares que operaban bajo el mando del gobernador Andonaegui en la conflictiva región de frontera con las posesiones portuguesas. Con ocasión de la expedición de demarcación de límites del gobernador Andonaegui, Martín de Sarratea entablaría contacto con Martín de Altolaguirre, entonces comisario de guerra. Algunos años después, a fines de la década de 1760, Sarratea (que en 1762 había sido nombrado por el gobernador Cevallos como teniente de una de las compañías organizadas para tomar Colonia del Sacramento), casaría con doña Tomasa de Altolaguirre, hija de aquél, y consolidaba mediante el parentesco sacramental una base para la extensión de la red bajo otras formas de enlaces. Desde entonces, Sarratea administraría comercialmente el crédito mercantil y monetario de Altolaguirre, a quien competía sostener una formal asepsia como factor de la Real Hacienda en Buenos Aires.

Sarratea era coetáneo del segundo hijo de su suegro, Martín José de Altolaguirre, quien heredaría el cargo de factor de su padre, y con quien continuaría desplegando negocios, lo que garantizaba la reproducción intergeneracional de la red. Es comprensible, por lo tanto, su actuación como asentista de víveres desde 1770, cuando Martín José de Altolaguirre ya está en funciones como factor. Ello le permitía hacerse de considerables y frecuentes desembolsos desde el ramo de Situados de Buenos Aires, por su provisión de víveres "que esta subministrando y ha subministrado a la tropa y embarcaziones de Su Magestad" ${ }^{46}$. Llegaría a acumular, por este concepto y al menos entre 1770 y 1772 , la cuantiosa suma de $\$ 430.858,7$.

Aun cuando el gobernador Bucarelli desplazase del Real Servicio a Sarratea tras acusaciones de participación en el contrabando, su reposicionamiento en el Cabildo de Buenos Aires -desde donde continuaría enfrentándose a Bucarelli- le permitiría seguir articulando estrategias económicas y políticas. En efecto, desde 1779 Sarratea fue uno de los apoderados de la Junta de Comercio de Buenos Aires hasta la fundación del Consulado de Comercio en 1794, en el cual seguiría siendo un actor protagónico -llegó a desempeñarse como prior y como consiliario (Kraselsky, 2011)-. Sarratea era igualmente apoderado, o factor, de la Real Compañía de Filipinas en el Río de la Plata (Kraselsky, 2011, p. 203), y es claro que al morir su legado continuaría desplegando recursos patrimoniales y relacionales ${ }^{47}$.

Los tres casos abordados nos permiten sugerir que los desembolsos del Real Situado sólo podían tener efectividad para sostener la defensa en la medida en que estuviesen intermediados por la capacidad de provisión de estos proveedores y acreedores. Pero también nos demuestran que estos principales proveedores, a su vez, lograban colocar sus negocios por esta vía, no tanto en función de criterios de eficiencia mercantil sino a partir de negociaciones apuntaladas en relaciones interpersonales: lógica de una Hacienda "contratadora"que optaba por apelar a los asientos con agentes e intermediarios particulares antes que a la administración directa, aun cuando la asignación de los contratos resultase más onerosa que una potencial minimización de costos en el mercado o en la internalización de la producción de los suministros, por cuanto 
también en estas fronteras del imperio borbónico existía un criterio pragmático para asegurar los suministros militares ${ }^{48}$.

Entretanto, el hecho de que los desembolsos para el reintegro a acreedores y proveedores procediera de autos provistos por los propios oficiales reales antes que de decretos, órdenes o autos emanados del gobierno (como ocurría en la mayoría de las partidas de data destinadas al pago de sueldos) pone en evidencia que la prelación de estos pagos respondía a una capacidad de acción y negociación, sostenida en lazos como los que hemos descripto entre oficiales reales y acreedores o proveedores.

Desde luego, los asentistas de víveres no eran los únicos proveedores y acreedores de la Hacienda local. Tal como se señalase anteriormente, aquellos tres asentistas estaban escoltados en su condición de acreedores de la Hacienda por "individuos del comercio", que aún no se hallaban representados corporativamente pero que actuaban colectivamente en operaciones financieras con el Erario regio. Así, el primero de marzo de 1768, el gobierno disponía que se les pagase del ramo de Situados la suma de \$52.844,1 a "quarenta individuos de este comercio que hicieron suplemento a SM", en pago por "cantidades con que concurrieron para las urgencias del Real Servicio". Puntualmente, se les estaba retribuyendo en moneda doble por los préstamos que efectuaron en noviembre de 1767 para cubrir los gastos de la fragata Venus (que desde la ensenada de Barragán llevaría a la Península unos 150 jesuitas expulsados) y diversas erogaciones implicadas en las expediciones a Islas Malvinas ${ }^{49}$. Ese mismo mes, los oficiales de la Real Caja volverían a desembolsar unos \$25.804,6 en moneda doble a "quarenta y ocho individuos de este comercio a buena quenta de los suplementos que hicieron a SM" por el mismo concepto que en la ocasión previa ${ }^{50}$. De esta manera, el colectivo de comerciantes porteños recibía en 1768 la elevada suma de $\$ 78648,7$ en concepto de repago por créditos otorgados a la Hacienda para la defensa.

Un tercer renglón de acreditación financiera lo constituían las transferencias procedentes de otros ramos, que entre 1767 y 1770 ascendieron a \$115.000. Un mecanismo de financiación interna, arcaico, que avanzaría con el correr del siglo XVIII ${ }^{51}$. Pero resulta destacable que en todos los casos en los que se realizaban transferencias desde el ramo de Situados hacia otros ramos, la operación contable respondía a la necesidad de saldar deudas que habían sido contraídas por la Hacienda mediante el ingreso del crédito en aquellos otros ramos, y que encontraban fondos disponibles para su rembolso en este ramo de Situados. De esta manera, el 12 de marzo de 1767 se sacaban $\$ 75.000$ del ramo de Situados, "pasados al ramo de la expedicion a las Islas Malvinas y descubrimiento de la Tierra del Fuego, para satisfacer a cinco individuos de este comercio que suplieron a SM igual cantidad en los dias seis y siete de febrero proximo pasado" 52 . En una misma sintonía, en mayo de 1768 se sacaban $\$ 10.000$ del ramo y se los traspasaban a otro "para satisfacer los creditos contrahidos contra la Real Hacienda durante el tiempo que governo esta provincia el excelentisimo señor governador don Pedro de Cevallos" ${ }^{53}$, operación que se repetiría en los mismos términos en octubre de 1768, en mayo de 1769 y nuevamente en mayo de $1770^{54}$.

De esta manera, la Hacienda real dependía no sólo del crédito de los asentistas, sino del crédito de individuos del comercio que aportasen suplementos monetarios de manera sistemática. A ellos se agregaría, desde luego, una extensísima nómina de acreedores menores, quienes con sus préstamos y provisiones sostenían la capacidad de la Hacienda para volver operativa la defensa del Río de la Plata, y que intermediaban en la gestión de los recursos del Real Situado.

\section{Conclusiones}

Don Miguel Ruiz Arellano, que se hacía reconocer como “capitán mayor de las tropas y estancias del rey”, había anticipado suplementos por \$4.399 "a los Blandengues y Peones que hacen el Real Servicio en los puertos de la otra vanda, por via de socorro”. Este rol como acreedor de la Hacienda le serviría para desplegar su crédito en la economía local: el 23 de octubre de 1769, un “vezino de esta ciudad”, don Tomás Guzmán, 
recibía de manos del tesorero Juan Francisco de Aldao la importante suma de \$4.399, descargada del ramo de Situados. Es que un papel firmado por Ruiz Arellano endosaba a favor de Guzmán el crédito que aquél tenía contra la Real Hacienda, saldando así sus tratos mediante una precaria monetización de las deudas del Erario $^{55}$.

La distribución que los oficiales reales hicieron entre 1766 y 1772 de los recursos del Real Situado de Buenos Aires pone en evidencia que la característica estructural de la Hacienda en esta frontera imperial era su endeudamiento sistémico. Un endeudamiento que desbordaba la órbita de la administración de las finanzas reales para encarnar en la economía local, tal como lo demuestra el endoso de Ruiz Arellano a Guzmán.

La gestión de los recursos del Situado lo corrobora. Por empezar, el $26 \%$ de los recursos del Situado era destinado a saldar deudas con acreedores y proveedores de diversa naturaleza: asentistas de víveres, un colectivo de comerciantes porteños que aún no se había instituido corporativamente, pequeños tratantes y acreedores ocasionales. Todos ellos intermediaban en el desembolso de los caudales del Situado, captando porciones del mismo como reintegro de suministros, suplementos, socorros y anticipos que posibilitaban operativamente el ejercicio de la defensa.

Esta apelación a proveedores y acreedores particulares, en un contexto en el que la Hacienda rioplatense comenzaba a experimentar una creciente gravitación de Buenos Aires como plaza receptora de fondos por vía del Situado, viene a evidenciar que centralización y negociación no resultaban mutuamente excluyentes como modelos de gobierno de la Hacienda real: si la prioridad borbónica era que los soldados contaran con alimento, uniformes o sables, con independencia del modo empleado para su obtención, el Río de la Plata parece haber participado de ese criterio pragmático que se evidencia en la escala imperial (Torres Sánchez, 2013, p. 170). En este sentido, y tal como se hubiese planteado en otra ocasión (Wasserman, 2016a), esta conexión estructural entre los fondos de la Hacienda y el crédito particular viene a constatar la dificultad de plantear una distinción nítida entre lo público y lo privadopara comprender la administración y el gobierno de la Hacienda monárquica, volviendo cuestionable la suposición de la naturaleza "externa" del gasto ejecutado por la Corona mediante la apelación a agentes particulares (Grafe e Irigoin, 2008b, p. 238).

A su vez, la participación de habilitados en la recepción de los sueldos para su distribución entre los efectivos de las unidades a las que representaban implicaba el desembolso de fondos del Situado en manos de sujetos con potestad legítima para recibirlos, ocasión en la que los habilitados podrían haber operado como intermediarios en la liquidación de reintegros a los acreedores que hubiesen provisto a crédito a las tropas. Si bien este punto aún constituye una hipótesis de trabajo (antes que un argumento empíricamente refrendado para el período que estamos abordando), tanto el resto del análisis como la historiografía al respecto sugieren que estos actores también participaban en la intermediación, negociación y distribución de fondos del Situado en redes crediticias desplegadas para suplir a las tropas ante la sistemática demora en las pagas.

Y cuando volvemos la atención al ritmo de desembolso de esos mismos sueldos, también se advierte que aquel sistemático retraso en la liquidación de los sueldos suponía, en los hechos, un endeudamiento estructural de la Corona con las tropas que defendían su jurisdicción en territorios de frontera. Los efectivos de estas unidades, que nutrían al grueso de la población rioplatense, eran los principales acreedores de una Hacienda cuya morosidad se revelaba insostenible allí cuando se traducía en elevadas tasas de deserción.

Si la cita que abre estas conclusiones nos habla de un posible proceso de germinal monetización de la deuda de la Hacienda, también nos habla de las implicancias de ese endeudamiento y de esa monetización. El 12 de enero de 1769, Ruiz Arellano había logrado obtener de la Real Caja de Buenos Aires unos \$1.200 "por sus salarios vencidos en treinta meses" (esto es, el sueldo de dos años y medio "al respecto de quarenta pesos al mes") ${ }^{56}$. La magnitud de este endeudamiento local de la Hacienda real explica que sus acreedores se viesen empujados, como lo hiciera Ruiz Arellano nueve meses más tarde, a dar un uso creativo de la deuda regia para saldar sus propios compromisos y necesidades ${ }^{57}$. 


\section{REFERENCIAS}

Alemano, M. E. (2016). El imperio desde los márgenes: la frontera del Buenos Aires borbónico (1752-1806) (Tesis de doctorado), Universidad de San Andrés, Buenos Aires, Argentina.

Alves Carrara, A., y Sánchez Santiró, E. (2012). Guerra y fiscalidad en la Iberoamérica colonial (siglos XVII-XIX), Editorial UFJF-Instituto Mora, Juiz de Fora.

Amadori, A. (2012). Fiscalidad y consenso en el Virreinato del Perú, 1620-1650. Am. Lat. Hist. Econ., año 19, 2(38), $7-45$.

Amaral, S. (2014). Las finanzas arcaicas: la atención del déficit fiscal en la Real Caja de Buenos Aires, 1789-1811. Investigaciones y Ensayos, 60, 381-436.

Amaral, S. (2015). Seguridad monárquica, inseguridad republicana: la modernización de las finanzas públicas en Buenos Aires, 1790-1821. En P. González Bernaldo [Dir.]. Independencias iberoamericanas. Nuevos problemas y aproximaciones (pp. 217-236). Buenos Aires: Fondo de Cultura Económica.

Bertrand, M. (2011). Grandeza y miseria del oficio. Los oficiales de la Real Hacienda de la Nueva España, siglos XVII y XVIII. México: Fondo de Cultura Económica.

Bertrand, M., Dubet, A., Solbes Ferri, S., y Torres Sánchez, R. (2014). Haciendas locales y haciendas estatales en las Monarquías francesa y española. La construcción territorial del poder (siglo XVIII). Espacio, Tiempo y Forma, Serie IV, Historia Moderna, 27.

Beverina, J. (1992 [1935]). El Virreinato de las Provincias del Río de la Plata. Su Organización Militar. Contribución a la "Historia del Ejército Argentino". Buenos Aires: Círculo Militar.

Biangardi, N. (2016). Financiamiento y distribución del gasto en la Caja Real de Maldonado (Río de la Plata), 1782-1806. América Latina en la Historia Económica, año 23, 2, 7-35.

Birocco, C. M. (2015). El presidio de Buenos Aires entre los Habsburgo y los Borbones: el ejército regular en la frontera sur del imperio español. En E. Reitano y P. Possamai (Coords.), Hombres, poder y conflicto. Estudios sobre la frontera colonial sudamericana y su crisis (pp. 117-150). La Plata: FaHCE-UNLP.

Birolo, P. (2015). Militarización y política en el Rio de la Plata colonial. Cevallos y las campañas militares contra los portugueses, 1756-1778. Buenos Aires: Prometeo.

Carbia, R., y De Gandía, E. (1939). Historia de la ciudad de Buenos Aires, Tomo I, Buenos Aires: M.C.B.A.

Concolorcorvo (La Vandera, Alonso Carrió y Calixto Bustamante Carlos Inca), (2005 [1773]). El lazarillo de ciegos caminantes. Desde Buenos Aires hasta Lima. Buenos Aires: Stockcero.

Cuesta, E. M. (2009). Precios, Población, Impuestos y Producción. La economía de Buenos Aires en el siglo XVIII. Buenos Aires: Temas.

Daniels, C., \& Kennedy, M. (Eds.) (2002). Negotiated Empires: Centers and Peripheries in the Americas, 1500-1820. New York-London: Routledge.

Dedieu, Jean-Pierre (2018). De la merced a la deuda: la Monarquía española y el crédito en el siglo XVIII. En M. Bertrand y Z. Moutoukias (Eds.). Cambio institucional y fiscalidad. Mundo hispánico, 1760-1850 (pp. 25-41). Madrid: Casa de Velázquez.

Destefani, L. (1970). Historia naval argentina. Buenos Aires: Armada Argentina.

Fradkin, R. (2012). Guerras, ejércitos y milicias en la conformación de la sociedad bonaerense. En R. Fradkin (Dir.), Historia de la Provincia de Buenos Aires. De la conquista a la crisis de 1820 (pp. 245-273). Buenos Aires: UNIPEEdhasa.

Frías, S. (1995). La seguridad de la ciudad de Buenos Aires en la época de Martínez de Salazar. Separata de Res Gesta, 34, 119-145.

Garretón, A. (1933). La municipalidad colonial. Buenos Aires, desde su fundación, hasta el gobierno de Láriz. Buenos Aires: Jesús Menéndez.

Gelman, J. (2012). La economía de Buenos Aires. En R. Fradkin (Dir.), Historia de la Provincia de Buenos Aires. De la conquista a la crisis de 1820 (pp. 85-121). Buenos Aires: UNIPE-Edhasa. 
Gelman, J., y Moraes, M. I. (2014). Las reformas borbónicas y las economías rioplatenses: cambio y continuidad. En J. Gelman, C. Marichal y E. Llopis (Eds). Iberoamérica y España antes de las independencias, 1700-1820. Crecimiento, reformas y crisis (pp. 31-74). México: Instituto Mora/El Colegio de México.

González Enciso, A. (2008). El estado fiscal-militar, una reflexión alternativa. Memoria y Civilización, 11, 271-295.

Grafe, R., \& Irigoin, A. (2008a). Bargaining for Absolutism. A Spanish Path to Empire and Nation Building. The Hispanic American Historical Review, 88(2), 173-209.

Grafe, R. \& Irigoin, A. (2008b). Response to Carlos Marichal and William Summerhill. The Hispanic American Historical Review, 88(2), 235-245.

Grieco, V. (2014). The Politics of Giving in the Viceroyalty of Rio de la Plata. Donors, Lenders, Subjects, and Citizens. New Mexico: University of New Mexico Press.

Groussac, P. (1936). Las Islas Malvinas. Buenos Aires: Comisión Protectora de Bibliotecas Populares.

Gustafson, L. S. (1988). The Sovereignty Dispute Over the Falkland (Malvinas) Islands. New York-Oxford: Oxford University Press.

Jumar, F., y Sandrín, M. E. (2015). El gasto público como dinamizador de la economía local. Río de la Plata, en la primera mitad del siglo XVIII. En E. Sánchez Santiró [Coor.], El gasto público en los imperios ibéricos, siglo XVIII (pp. 205-272). México: Instituto Mora - CONACyT.

Klein, H., y TePaske, J. (2005 [1982, 1986, 1989]). Las cartas cuentas de la Real Hacienda de la América Española, siglos XVI a principios del siglo XIX. México: Edición electrónica, AMHE.

Kraselsky, J. (2011). Las estrategias de los actores del Río de La Plata: Las juntas y el Consulado de Comercio de Buenos Aires a fines del Antiguo Régimen 1748-1809 (Tesis de posgrado), Universidad Nacional de La Plata, Facultad de Humanidades y Ciencias de la Educación, La Plata, Argentina.

Kuethe, A. (2005). Las milicias disciplinadas en América. En J. Marchena Fernández y A. Kuethe (eds.). Soldados del Rey. El Ejército Borbónico en América Colonial en visperas de la Independencia (pp. 103-126). Castellón: Ed. Universitat Jaume I.

Kuethe, A. (2007). Conflicto internacional, orden colonial y militarización. En E. Tandeter (Dir.), Historia General de América Latina, Vol. IV (pp. 325-348). Madrid: UNESCO.

Levene, R. (1952 [1927-8]). Investigaciones acerca de la historia económica del Virreinato del Plata, vol. I y II. Buenos Aires: El Ateneo.

Marchena Fernández, J. (2001). La defensa del Imperio. En A. Castillero Calvo (Dir.), Historia general de América Latina, v. III, t. 2 (pp. 615-668). París: UNESCO.

Marchena Fernández, J. (2014). Llevar la guerra al otro lado del mundo: Reforma e Ilustración en las guerras de España contra Portugal. La gran expedición militar al Brasil y al Río de la Plata de 1776. En M. Baudot Monroy (Ed.), El Estado en guerra. Expediciones navales españolas en el siglo XVIII (195-260). Madrid: Ed. Polifemo.

Marichal, C. (1999). La Bancarrota del virreinato. Nueva España y las finanzas del Imperio español, 1780-1810. México: FCE.

Marichal, C., y Grafenstein, J. (Coords.) (2012). El secreto del imperio español: los situados coloniales en el siglo XVIII. México: El Colegio de México/Instituto de Investigaciones Dr. José María Luis Mora.

Marichal, C. y Souto, M. (2012). La Nueva España y el financiamiento español en América: los situados para el Caribe en el siglo XVIII. En J. Grafenstein y C. Marichal (Coords.), El secreto del imperio español: los situados coloniales en el siglo XVIII (pp. 61-94). México: El Colegio de México/Instituto de Investigaciones Dr. José María Luis Mora.

Mariluz Urquijo, J. M. (2000). El Tribunal Mayor y Audiencia Real de Cuentas de Buenos Aires. Revista Española de Control Externo, 2(4), 129-158.

Mayo, C. (1987). Sociedad rural y militarización de la frontera en Buenos Aires, 1737-1810. Jahrbuch für Geschichte von Staat, Wirtschaft und Gesellschaft Lateinamerikas, 24, 251-263.

Meisel Roca, A. (2002). Crecimiento a través de los subsidios: Cartagena de Indias y el situado, 1751-1810. Cuadernos de Historia Económica y Empresarial, 9. (pp. 1-25).

Millé, A. (1972). La cuenca del Plata. Antecedentes para su historia. Buenos Aires: Emecé. 
Mörner, M. (1986). Actividades politicas y económicas de los jesuitas en el Río de la Plata. Buenos Aires: Hyspamérica. Mououtkias, Z. (1992). Réseaux personnels et autorité coloniale. Les négociants de Buenos Aires au XVIIIe siècle. Annales ESC, 4-5, 889-915.

Moutoukias, Z. (1988a). Contrabando y control colonial en el siglo XVII. Buenos Aires: el Atlántico y el espacio peruano. Buenos Aires: CEAL.

Moutoukias, Z. (1988b). Power, Corruption, and Commerce: The Making of the Local Administrative Structure in Seventeenth-Century Buenos Aires. The Hispanic American Historical Review, 68(4), 771-801.

Moutoukias, Z. (1995). El crecimiento en una economía colonial de Antiguo Régimen: reformismo y sector externo en el Río de la Plata (1760-1796). Arquivos do Centro Cultural Calouste Gulbenkian, (34), 771-813.

North, D. C., Summerhill, W. \& Weingast, B. R. (2000). Order, Disorder and Economic Change: Latin America vs. North America. En B. Bueno de Mesquita y H. L. Root (Eds.), Governing for Prosperity (pp. 17-58). New HavenLondon, Yale University Press.

North, D. \& Weingast, B. (1989). Constitutions and Commitment: The Evolution of Institutional Governing Public Choice in Seventeenth-Century England. The Journal of Economic History, XLIX(4), 803-832.

Pacheco Díaz, A. (2012). Las transferencias fiscales novohispanas a Puerto Rico: siglos XVI-XIX. En J. Grafenstein y C. Marichal (Coords.), El secreto del imperio español: los situados coloniales en el siglo XVIII (pp. 115-142). México: El Colegio de México/Instituto de Investigaciones Dr. José María Luis Mora.

Pardo de Guevara y Valdés, E. (Ed.) (2015). Actas de la XI Reunión Americana de Genealogía. España y América: un escenario común. Santiago de Compostela: CSIC-Xunta de Galicia-Instituto de Estudios Gallegos "Padre Sarmiento".

Pincus, S., y Robinson, J. (2016). Faire la guerre et faire l'État: Nouvelles perspectives sur l'essor de l'État développementaliste. Annales. Histoire, Sciences Sociales, 71st year, (1), 5-36.

Quarleri, L. (2015). La guerra guaranítica (1753-1756). Política, representaciones e ideología. En F. Lorenz (Comp.), Guerras de la historia argentina (pp. 29-48). Ariel: Buenos Aires.

Rees Jones, R. (1992). El Superintendente Manuel Ignacio Fernández (1778-1783). Las reformas borbónicas en el Virreinato de Buenos Aires. Buenos Aires: Instituto de Investigaciones de Historia del Derecho.

Saguier, E. (1989). La conducción de los caudales de oro y plata como mecanismo de corrupción. El caso del situado asignado a Buenos Aires por las Cajas Reales de Potosí en el siglo XVIII. Historia, 24, 287-317.

Saguier, E. (2004/2007). Un Debate Histórico Inconcluso en la América Latina (1600-2000). Cuatro siglos de lucha en el espacio colonial peruano y rioplatense y en la argentina moderna y contemporánea, Buenos Aires, 2004/2007, Tomo IX, Cap. 2, http://www.er-saguier.org/

Sanchez Santiró, E. (2013). Corte de Caja. La Real Hacienda de Nueva España y el primer reformismo fiscal de los Borbones (1720-1755). Alcances y contradicciones. México: Instituto Mora.

Sánchez Santiró, E. (2016). Las reformas borbónicas como categoría de análisis en la historiografía institucional, económica y fiscal sobre Nueva España: orígenes, implantación y expansión. Historia Caribe, 11(29), 19-51.

Sandrín, M. E. (2014). La actividad económica de los asentistas de víveres de la Marina de Montevideo, 1770-1810. América Latina en la Historia Económica. Revista de Investigación, 21(1), 92-114

Santilli, D. (2013). ¿Perjudiciales o beneficiosas? La discusión sobre el impacto económico de las reformas borbónicas en Buenos Aires y su entorno. Fronteras de la Historia, 18(2), 247-283.

Schlez, M. (2013). Los circuitos comerciales tardo-coloniales. El caso de un comerciante monopolista: Diego de Agüero (1770-1820) (Tesis Doctoral), Facultad de Filosofía y Letras, Universidad de Buenos Aires, Argentina.

Sierra, V. (1959). Historia de la Argentina, 1700-1800. Buenos Aires: Unión de Editores Latinos.

Solbes Ferri, S. (2015). Gasto militar y agentes privados. La provisión de uniformes para el ejército español en el siglo XVIII. Tiempos Modernos, 30(1), 1-18.

Solbes Ferri, S., Dubet, A., Bertrand, M. y Torres Sánchez, R. (2015). Actores políticos y actores privados en el gobierno de la Hacienda. Tiempos Modernos, 30(1), 1-8. 
Summerhill, W. (2008). Fiscal Bargains, Political Institutions, and Economic Performance. The Hispanic American Historical Review, 88(2), 219-233.

Tandeter, E. (1991). El eje Potosí-Buenos Aires en el imperio español. En M. Ganci y R. Romano (Dir.), Governare il mondo. L'imperio spagnolo dal XV al XIX secolo (pp. 185-202). Palermo: Società Siciliana per la Storia PatriaInstituto di Storia Moderna-Gacoltà di Lettere.

Torres Sánchez, R. (2013). Administración o asiento. La política estatal de suministros militares en la Monarquía española del siglo XVIII. Studia Historica: Historia Moderna, 35, 159-199.

Torres Sánchez, R. (2015). El gasto público en la España del siglo XVIII. En E. Sánchez Santiró (Coord.), El Gasto Público en los imperios ibéricos, siglo XVIII (pp. 23-72). México: Instituto Mora.

Torres Sánchez, R. (2016). Military Entrepreneurs and the Spanish Contractor State in the Eighteenth Century. Oxford: Oxford University Press.

Valle Pavón, G. del (2016). Donativos, préstamos y privilegios. Los mercaderes y mineros de la ciudad de México durante la guerra anglo-española de 1779-1783. México: Instituto Mora.

Wasserman, M. (2016a). Real Situado y gestión patrimonial del recurso fiscal. Remesas para defensa del puerto de Buenos Aires en el siglo XVII. Nuevo Mundo, Mundos Nuevos, Mondes Américains, 1-26.

Wasserman, M. (2016b). Los nombres propios del gasto. Procedencia, finalidades y receptores de los recursos erogados por la Real Caja de Buenos Aires en el siglo XVII. Escuela de Historia, 15(2), 1-22.

Wasserman, M. (2016c). El Tribunal de Cuentas de Buenos Aires: un observatorio del cambio institucional en el Río de la Plata borbónico (1768-1777). XXV Jornadas de Historia Económica de la Asociación Argentina de Historia Económica, Salta, Facultad de Humanidades de la Universidad Nacional de Salta, pp. 1-37.

Wasserman, M. (2017). Recursos fiscales para administrar el Imperio. La gestión de los ingresos al ramo de Situados de Buenos Aires, 1766-1784. Estudios del ISHiR, 19, 82-115.

Wayar, A. (2011). Las remesas fiscales intra-coloniales. Una aproximación desde las cajas del Tucumán. 1759-1808. En VJornadas uruguayas de Historia Económica, Montevideo.

Yun Casalilla, B. (2009). Introducción. Entre el imperio colonial la monarquía compuesta. Élites y territorios en la Monarquía Hispánica (ss. XVI y XVII). En B. Yun Casalilla (Dir.), Las Redes del Imperio. Élites sociales en la articulación de la monarquía hispánica, 1492-1714 (pp. 11-38). Madrid: Marcial Pons.

\section{Notas}

1 La bibliografía al respecto es amplia, pero es preciso rescatar las obras de Marichal y Grafenstein (2012, p. 15); Alves Carrara y Sánchez Santiró (2012); Marichal (1999). En este sentido, la Real Hacienda en Buenos Aires participaba de la lógica con la que se articulaba el erario en el resto del imperio hispanoamericano. Al igual que en otros distritos fiscales de la Monarquía y en consonancia con la prioridad que todos los gobiernos imperiales daban a la actividad militar durante los siglos XVII y XVIII (Torres Sánchez, 2015: 27; Pincus y Robinson, 2016; González Enciso, 2008), la Caja porteña también concentraba buena parte de sus desembolsos en erogaciones con fines defensivos.

2 Véase Gelman (2012). Una enriquecedora discusión sobre las variables que incidieron en el crecimiento económico de la región rioplatense durante la segunda mitad del siglo XVIII, y sobre el alcance de las reformas en ese proceso, es ofrecida en Moutoukias (1995).

3 Estudios de caso en Birocco (2015); Saguier (1989); Wasserman (2016a y 2016b). Para otras latitudes, véase Solbes Ferri (2015); Bertrand, Dubet, Solbes Ferri y Torres Sánchez (2014) y Solbes Ferri, Dubet, Bertrand y Torres Sánchez (2015). Esta participación de los intereses de grupos dominantes americanos en la órbita fiscal se encuadra en una estructura imperial apuntalada en buena medida sobre la negociación con las oligarquías locales, tal como puede observarse en Amadori (2012); Bertrand (2011); Yun Casalilla (2009); Daniels y Kennedy (2002).

4 Con ello, habrían de atenuarse a un mismo tiempo los contrastes que el Nuevo Institucionalismo Económico identificaba entre el sistema fiscal español y el angloamericano, con implicancias sobre el rol asignado a dichos sistemas en la divergencia de largo plazo. Véase North y Weingast (1989); North, Summerhill y Weingast, (2000).

5 Sobre este tópico puede consultarse Grafe e Irigoin (2008a); Wayar (2011); Valle Pavón (2016); Sánchez Santiró (2016); Grieco (2014). 
6 Ver al respecto Jumar y Sandrín (2015) y Meisel (2002). Para una perspectiva diferente sobre el impacto de las remesas de recursos fiscales en las economías receptoras, véase Summerhill (2008).

7 El interrogante referido adquirió relevancia recientemente en la historiografía a través del estudio de los mecanismos de suministros militares, los criterios para asignar recursos a sus proveedores y las implicancias de esas elecciones monárquicas para la consolidación de su autoridad política en el gobierno de la Hacienda. Al respecto, véase Torres Sánchez (2016).

8 Las 10.000 personas a que asciende aproximadamente la cantidad de efectivos involucrados en milicias (hacia 1765) más unidades veteranas (hacia 1771) adquieren una impactante participación sobre la estimación poblacional que ofrece Concolorcorvo para 1770 (22.000 habitantes).

9 La población total estimada de Buenos Aires en 1744 alcanzaba los 11.600 habitantes, en 1778 superaba los 26.000 (alcanzando los 37.100 al contemplar su entorno rural) y en 1810 llegaba a 42.250 (92.000 incorporando la campaña): síntoma suficientemente vívido de crecimiento económico. Véase Moutoukias (1995), en donde se aprecia la relación con la dinámica exportadora del puerto. Véase asimismo Gelman (2012) y Santilli (2013).

10 Cuesta (2009, pp. 194 y ss.).

11 Retomando datos ofrecidos por Halperín Donghi, TePaske y Klein, Tandeter (1991, p. 199) explica que en los años 1791-1795 las remesas de Potosí a Buenos Aires representaron el 75,80 \% de los ingresos de la Villa Imperial, en tanto que esa participación se mantuvo en 64,10 \% durante 1796-1800.

12 Coinciden en esto Gelman (2012) y Cuesta (2009). La inflexión experimentada en 1779, que queda afuera del arco cronológico del presente artículo, puede leerse en Wasserman (2017).

13 Sobre la articulación entre Montevideo y Malvinas, véase Groussac (1936, pp. 117-143); Destefani (1970, p. 12); Rees Jones (1992, p. 203); Sierra (1959, p. 374).

14 El proceso puede consultarse en Mariluz Urquijo (2000, p. 133); Levene (1952 [1927-8], v. II, p. 247); Rees Jones (1992, p. 108).

15 Un segundo salto cuantitativo en los caudales enviados a Buenos Aires ocurre durante la segunda mitad de la década de 1770. Véase Wasserman (2017).

16 Dichos desembolsos se realizaron bajo los rótulos de "Malvinas", "Gastos de fragatas, viveres de tropa de tierra, Malvinas y reconocimiento de las costas de Patagones”, y "Gastos en los nuevos establecimientos de las Malvinas, Isla del Fuego, Costa de Patagones y embarcaziones que se hallan empleadas en estas espediziones”. AGN, XIII, 42-01-19, “1768-1777. Caja de Buenos Aires. Resumen de Ajustes a las Tropas, Embarcaciones de Su Majestad y Gastos. Razón de los Situados recibidos de Potosí". Ver al respecto, Wasserman (2016c).

17 El Real Decreto para la ejecución del extrañamiento de los regulares de la Compañía de Jesús, firmado en 5 de febrero de 1767, era acompañado por una Real Cédula del 5 de abril de ese año, que disponía su cumplimiento en América y que se procediese, asimismo, al secuestro de sus temporalidades. El 3 de julio de 1767 eran notificados los jesuitas del Colegio de Buenos Aires e inventariados sus bienes; lo mismo ocurriría el 6 de julio en Montevideo, el 12 en Córdoba, el 13 en Santa Fe y el 21 en Corrientes. Recién al año siguiente, el 16 de julio de 1768, comisionados de Bucareli notificaban el Real Decreto a los jesuitas en Yapeyú, luego de negociaciones de Bucareli con corregidores y jefes guaraníes de las misiones de la provincia jesuítica del Paraguay. El 20 de julio de 1768 comenzaban a ser trasladados a Salto los jesuitas que habían sido congregados en Yapeyú; el 14 de octubre de 1768 llegaba a Buenos Aires el último de los barcos que transportaba regulares de las misiones para su envío a Cádiz. Véase Millé (1972, pp. 286 y ss.).

18 Véase AGN, XIII, 42-01-19; Wasserman (2016c).

19 Louis Antoine de Bougainville, que en 1764 había comandado la expedición francesa fundadora del puerto Saint Luis en Islas Malvinas, hacía cesión formal de las islas a la corona española el $1^{\circ}$ de abril de 1766 , y se rebautizó aquel puerto con el nombre de Nuestra Señora de la Soledad. En 1765, entre tanto, una expedición británica había fundado Port Egmont donde Bougainville había reconocido la Croisade (en isla Trinidad). Comenzaba entonces una ocupación simultánea por España e Inglaterra, que suscitó la expedición de expulsión del destacamento británico al mando de Fernando Rubalcaba, quien partiría de Montevideo con destino a Islas Malvinas en la fragata Santa Catalina, en función de la orden que en julio de 1769 el gobernador Bucareli había dado desde Buenos Aires a Juan Ignacio Madariaga, jefe de la división naval de Montevideo (Groussac, 1936, p. 127). Rubalcaba llega a Puerto Soledad en enero de 1770 para afrontar la hostilidad británica en Croisade (Egmont) al mes siguiente. Los conflictos diplomáticos se sucederían hasta que en 1774 Egmont fuera evacuada por los propios británicos. Véase Groussac (1936, pp. 117-143); Destefani (1970, p. 12); Rees Jones (1992, p. 203); Sierra (1959, p. 374); Gustafson (1988, p. 19).

20 En ocasiones se aclaraba que los recursos se entregaban en Buenos Aires, por ejemplo, "para llevarlos a la plaza de Montevideo para socorrer a buena quenta a la tropa de invalidos que exciste en ella" (AGN, XIII, 42-1-20, f. 64r, 21 de octubre de 1766).

21 Considerando el Regimiento de Infantería de Mallorca, el Batallón de Voluntarios de Cataluña, el Batallón de la tropa antigua, el Batallón moderno de Buenos Aires, las tres compañías del Batallón de Santa Fe, el Regimiento de Dragones y la Compañía del Real Cuerpo de Artillería. 
22 Si tenemos en consideración las estimaciones de efectivos de las milicias para nuestro período, pueden reconocerse unas 3300 personas en milicias de Buenos Aires (entre el Batallón de Españoles de Buenos Aires, el Regimiento Provincial de Caballería de BA, el Cuerpo de Infantería de Negros Libres de BA, el Cuerpo de Caballería de Indios Guaraníes de BA, el Cuerpo de Caballería de Pardos de BA y el Cuerpo de Caballería de Indios Ladinos de BA), unas 2000 en milicias de la campaña bonaerense (Regimiento de Dragones Provinciales, Compañías del pago de Magdalena y Matanza, Compañías de Areco y Cañada Honda, Compañías de Arrecifes y Pergamino), más de 2000 efectivos en las compañías y milicias de Santa Fe y Corrientes, y unas 1100 personas en las milicias de Montevideo, la campaña montevideana y milicias de Santo Domingo Soriano, Víboras y Rosario. Véase Beverina (1992 [1935]) y Alemano (2016).

23 Mediante una Real Instrucción otorgada el 7 de julio de 1764 se establecían las milicias en la órbita de la gobernación de Buenos Aires, en función del modelo establecido para Cuba. En razón de ello, la Corona condujo 151 oficiales, sargentos, cabos y soldados veteranos a Buenos Aires para adiestramiento de voluntarios, junto a unos 2000 fusiles con bayoneta. Véase Kuethe (2005, p. 114).

24 Estas reformulaciones implicaron, durante los dos primeros meses de 1772, una emigración masiva y recambio de efectivos.

25 Agradezco a la autora la posibilidad de acceder a su valiosa tesis doctoral.

26 De allí que el presidio tuviese una instalación temprana: en 1631 el gobernador Pedro Esteban Dávila fundaría el presidio de Buenos Aires con una guarnición de tropas regulares, inicialmente compuesta de algo más de 50 soldados reclutados, y reconstruiría el fuerte de San Baltasar de Austria. La fortaleza experimentaría modificaciones y mejoras con el gobierno de José Martínez de Salazar desde 1663 y las tropas incrementarían sus filas a lo largo del siglo, ascendiendo a 300 en 1669 y 750 en 1677, para estimarse en unas 900 personas hacia 1684. Frías (1995, p. 123); Moutoukias (1988a, p. 41); Mörner (1986, pp. 188-190). Hasta 1631, la defensa militar del puerto se encontraba a cargo de una milicia de vecinos capitaneada por el gobernador o su teniente (o en su defecto por el alcalde de primer voto) y compuesta por cuatro compañías de a caballo con lanzas y adargas más dos compañías de infantería (Garretón 1933, p. 291). Un pequeño fuerte endeble y en constante reconstrucción, desde al menos fines de la década de 1590 sobre la boca del Riachuelo, era complementado con el fuerte amurallado construido por Hernandarias en 1618, que ya para 1623 sólo era "un flaco reparo de tapias caídas” (Carbia y De Gandía, 1939, p. 230). Con todo, esta guarnición militar participaba como el núcleo más numeroso del dispositivo burocrático-militar instalado en Buenos Aires por la Corona.

27 Ya en 1779 el Ramo de Guerra pasaría a la administración de la Aduana.

28 AGN, XIII, 42-1-24, f. 21v. Nuestros datos están ratificados en el citado trabajo de Alemano. "Mientras tanto", explica la autora, "el gasto en la frontera fue prácticamente nulo en aquellos años, los fuertes se habían herrumbrado y las compañías de blandengues languidecían” (Alemano, 2016).

29 El ejemplo está tomado de AGN, XIII, 42-1-20, f. 110v, 5 de octubre de 1768.

30 En el marco del Proyecto PICT-2017-4515, adjudicado a través de FonCyT por Res. 310/18. Agencia Nacional de Promoción Científica y Tecnológica, República Argentina.

31 Los retrasos en la llegada de estos recursos a Buenos Aires constituían la ocasión para que actores comerciales anticipasen a crédito bienes y servicios a una tropa desprovista de ingresos; con la llegada de las remesas monetarias a Buenos Aires, la Real Caja local direccionaba el pago en moneda a dichos acreedores en calidad de reintegro, permitiéndoles así el embolso de metálico que más difícilmente hubiesen obtenido a través de la oferta de los mismos bienes en sus tiendas (Moutoukias, 1988b, pp. 787-788; Saguier, 1989; Birocco, 2015; Autor/a, 2016a).

32 AGN, XIII, 42-1-21, f. 91v. También se le descontaba "lo correspondiente a un tres por ciento por el veneficio de la plata doble que ha percivido como parece de axustamiento citado decreto liquidacion y recivos que otorgó", lo que evidenciaba que el costo financiero del cambio monetario recaía sobre el sueldo de los efectivos. Sobre este aspecto volveremos a tratar en un trabajo en curso, y ya ha sido advertido en otra ocasión (Wasserman, 2017).

33 Será interesante ponderar esta distribución con las estimaciones ofrecidas por Jumar y Sandrín (2015) en su detallado estudio sobre la satisfacción de la demanda en el marco del sitio de Colonia del Sacramento entre 1735 y 1737.

34 En el caso montevideano, de acuerdo a Sandrín (2014, p. 97) los pagos eran estipulados cada cuatro meses.

35 AGN, XIII, 42-1-20, f. 80v.

36 El 31 de octubre de 1767 se le abonaban $\$ 12.000$ "en onze mil seiscientos cinquenta pesos quatro reales en plata doble, con el premio de tres por ciento”, por la provisión de víveres “a la tropa que guarneze los puestos de la Isla de Martin Garcia, Real de San Carlos, Puerto de Montevideo, Maldonado y Rio Grande”. AGN, XIII, 42-1-20, f. 89v.

37 AGN, XIII, 42-1-21, f. 56r, 23 de diciembre de 1769.

38 AGN, XIII, 42-1-21, f. 66v, 23 de mayo de 1770.

39 AGN, XIII, 42-1-21, f. 41r, 10 de enero de 1769.

40 AGN, XIII, 42-1-20, f. 105v, 30 de julio de 1768.

41 AGN, XIII, 42-1-21, f. 54v, 12 de diciembre de 1769.

42 AGN, XIII, 42-1-21, f. 103v, 19 de octubre de 1771.

43 AGN, XIII, 42-1-21, f. 104v, 9 de noviembre de 1771. 
44 AGN, XIII, 42-1-21, f. 82v, 24 de enero de 1771.

45 Tal como lo explicase Zacarías Moutoukias de manera detallada en un clásico trabajo, dicha red contaba con el gobernador Cevallos como aliado. Acusaciones y sentencias de la Audiencia de Charcas adversas a aquel grupo sirvieron, por lo tanto, para que Bucarelli -sucesor de Cevallos en el gobierno del Río de la Plata- desplazase de sus respectivos cargos a los oficiales reales. Bucarelli se serviría, en efecto, de la denuncia elevada contra dichos funcionarios por un mercader gallego, Domingo Lagos. Detenido por contrabando en 1764 bajo el gobierno de Cevallos y dado a la fuga, Lagos aguardaría a la llegada de Bucarelli para solicitarle clemencia a cambio de acusaciones contra aquella red, a la cual conocía por haberle servido antiguamente como organizador de sus contactos con Colonia del Sacramento. En tales acusaciones quedaba claro que Martín de Sarratea constituía un nodo estructural de dicha trama. Véase Moutoukias (1992).

46 AGN, XIII, 42-1-21, f. 80r, 29 de diciembre de 1770.

47 Baste con recordar que fue suegro del virrey Santiago de Liniers (casado en 1791 con María Martina de Saratea y Altolaguirre), y padre de Manuel de Sarratea (miembro del Primer Triunvirato).

48 Solbes Ferri (2015) identifica, en su estudio sobre el suministro de uniformes para el ejercito español, un patrón latino de "Contractor State" en la lógica de gestión de la monarquía borbónica durante el siglo XVIII. Sobre el pragmatismo como criterio primordial borbónico en el suministro de insumos para la guerra, véase Torres Sánchez (2013).

49 AGN, XIII, 42-1-20, f. 99r, $1^{\circ}$ de marzo de 1768.

50 AGN, XIII, 42-1-20, f. 100r, 29 de marzo de 1768.

$51 \mathrm{Al}$ respecto, véanse los trabajos de Amaral (2014 y 2015).

52 AGN, XIII, 42-1-20, f. 75r, 12 de marzo de 1767.

53 AGN, XIII, 42-1-20, f. 104r, 9 de mayo de 1768.

54 AGN, XIII, 42-1-20, f. 112r, 17 de octubre de 1768; AGN, XIII, 42-1-21, f. 45v, 28 de mayo de 1769 y f. 66r, 21 de mayo de 1770 .

55 AGN, XIII, 42-1-21, f. 49r, 23 de octubre de 1769.

56 AGN, XIII, 42-1-21, f. 41v, 13 de enero de 1769, "Data de 1.200 pesos pagados a don Miguel Arellano capitan mayor de las tropas del Rey por su sueldo vencido hasta fin de diziembre de 1768".

57 Quizás brotan, a través de estos poros fronterizos, las formas marginales con las que la Monarquía estaba creando una deuda permanente, incobrable, y ampliando su capacidad de endeudamiento de manera asimétrica. Sobre este punto se sugiere la lectura de Dedieu (2018). 